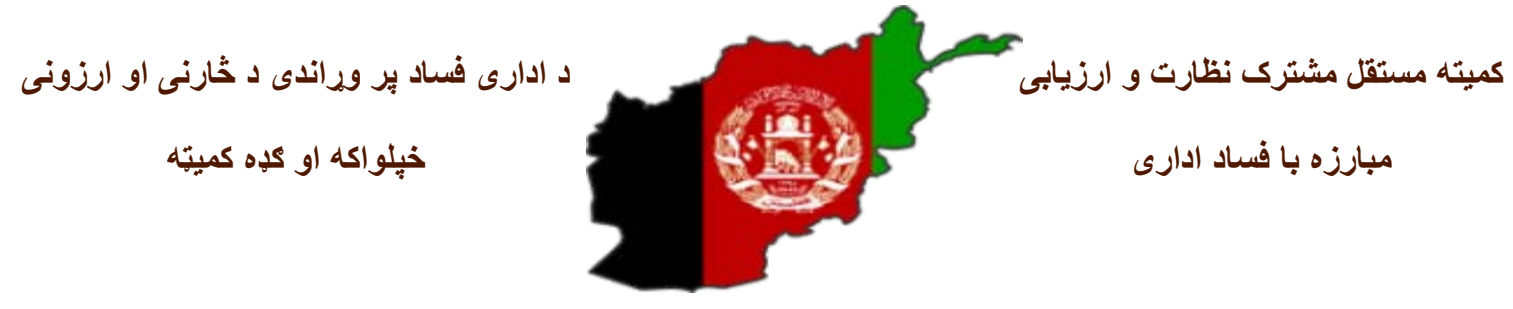

Independent Joint Anti-Corruption Monitoring and Evaluation Committee

\title{
A Review of Selected Foreign-Assistance Programs Implemented in Afghanistan
}




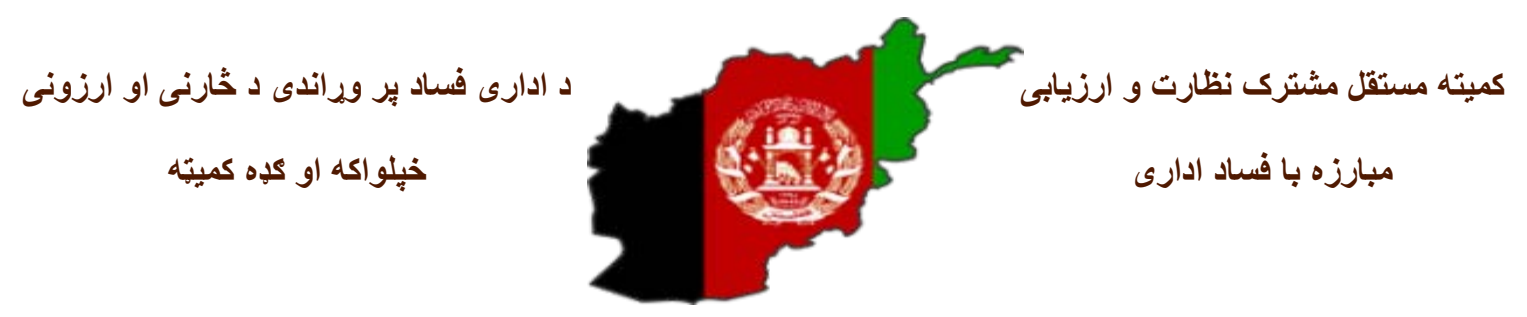

\author{
Independent Joint Anti-Corruption \\ Monitoring and Evaluation Committee
}

\title{
Message from the Committee
}

Since the overthrow of the Taliban, international donors have pledged more than $\$ 119$ billion ${ }^{1}$ in foreign assistance to Afghanistan. While the United States has been the largest donor-with the U.S. Congress having appropriated at least $\$ 109.8$ billion since 2002, $\$ 65.7$ billion of which went for security-related programs-other countries and organizations have played a crucial role in helping the Afghan government and people recover from decades of war, tyranny, and poor governance. ${ }^{2}$

This report examines projects in multiple sectors funded by different donor organizations in an attempt to extrapolate broader lessons about the overall foreign-assistance effort in Afghanistan. The objective of this report is not to conduct a comprehensive review, audit, or investigation of foreign assistance to Afghanistan over the past 13 years. Rather, MEC seeks to spotlight a selection of programs-all of which have their positive aspects, as well as their shortcomings-and contribute to the ongoing dialogue among stakeholders about how best to implement assistance programs in challenging environments, such as Afghanistan.

While this review was constrained by the unstable security situation and by some donors' legal restrictions on what information they could disclose, MEC was still able to review three U.K.-funded projects; three each by Norway, the European Union (EU), and Japan; and two by the United States. The projects were diverse in nature, from road construction to emergency humanitarian assistance. In addition, MEC also examined the extensive literature on other projects, drawing upon the work of academics and oversight organizations to present a more complete picture of our subject.

All of these projects were implemented under difficult conditions, with representatives from the various aid agencies and their partners often placing their lives at risk in order to accomplish the mission. It is hoped that the Afghan government and the donor community will view this report as it is intended, not as a document whose purpose is to affix blame, but rather as well-intentioned guidance for all parties concerned about the future of Afghanistan.

Sincerely,

Dr. Shaukat Hassan, MEC Chairman

\footnotetext{
${ }^{1}$ SIGAR, Quarterly Report to the U.S. Congress, January 2015, endnote 8, quoting the Islamic Republic of Afghanistan, Ministry of Finance, Development Cooperation Report 2012, p. 1. According to SIGAR, this "mid-2012 report is the most recent MOF summary of all external aid reported to the Afghan government." The actual total is likely higher.

2 SIGAR, Quarterly Report to the U.S. Congress, March 2015, pp. 64-67.
} 
Table of Contents

Executive Summary 4

Methodology $\quad 5$

Factors Hindering Foreign-assistance Programs 8

Countries/Agencies Featured 14

$\begin{array}{ll}\text { Projects Reviewed by Sector } & 16\end{array}$

$\begin{array}{ll}\text { Stabilization } & 16\end{array}$

$\begin{array}{ll}\text { Administrative Capacity Development } & 19\end{array}$

Gender Issues $\quad 23$

Security and Law Enforcement 24

$\begin{array}{ll}\text { Health } & 27\end{array}$

$\begin{array}{lr}\text { Agriculture } & 29\end{array}$

Infrastructure 33

$\begin{array}{ll}\text { Humanitarian Assistance } & 36\end{array}$

$\begin{array}{ll}\text { Suggested Policy Reforms } & 39\end{array}$

Conclusion 43

Acknowledgements $\quad 43$

Recommendations Separate Document 


\section{Executive Summary}

With the over throw of the Taliban in late 2001, the Government of the Islamic Republic of Afghanistan (GIRoA) became one of the world's largest recipients of foreign aid. ${ }^{3}$ According to the Ministry of Finance, almost $100 \%$ of its development budget and $45 \%$ of its operating budget is externally financed. ${ }^{4}$ This massive influx of money into a country with weak institutions, poor infrastructure, and a dearth of skilled professionals created massive opportunities for waste, fraud, and abuse.

That said, improvements have occurred as a result of assistance by donor governments and international organizations. For example, the establishment of democratic institutions and functional ministries; significant improvements in health care; a major expansion of primary education, for both boys and for girls; construction of thousands of miles of roads; and the formation of national-security forces capable, in some cases, of conducting effective, independent operations. Moreover, myriad laws have been passed that provide at least the framework for improved government operations, and several bodies have been established to track and monitor donor assistance, such as the Ministry of Finance's (MOF) Development Assistance Database (DAD) and the Afghanistan Financial Management Information System (AFMIS).

Notwithstanding these positive developments, Afghanistan remains one of the world's poorest countries. While GDP has increased from around $\$ 3$ billion in 2002 to $\$ 20$ billion in 2012 , in the absence of a viable economic base, there is little support for the proposition that such growth is sustainable. ${ }^{5}$ Most Afghans still endure conditions of hardship, with millions living in extreme poverty. Government institutions remain weak, and approximately $90 \%$ of public spending relies on foreign aid. According to the United Kingdom's Department for International Development (DFID), about half the population requires humanitarian assistance, and four-fifths depend on the fragile agricultural sector for their livelihoods. While misdirected aid and failed programs are not to blame for these conditions, they could have ameliorated them had they been better planned, executed, and coordinated with the Afghan government and with other donors. Too often, assistance was driven by donor priorities, instead of responding to Afghan requirements and preferences. Furthermore, too many projects were designed to deliver rapid, highly visible results to assuage the concerns of senior managers, rather than to achieve sustainable poverty reduction or capacity-building objectives.

To administer the state and to provide a basic standard of living for its people, the Afghan government depends on international-development assistance. But there are a number of factors that hinder effective use of external aid, including the lack of uniform aid-effectiveness indicators, complex delivery processes, high overhead and indirect costs, largely off-budget support from international donors, a lack of capacity in Afghan ministries, employment turnover in those ministries, an underdeveloped economic market, widespread corruption, and, most crucially, an unstable security situation. As the Afghan government noted in the paper it presented to the London Conference in December 2014:

\footnotetext{
${ }^{4}$ Ajmal Shams, "Afghanistan at the Crossroads," The Diplomat, http://thediplomat.com/2015/01/afghanistan-at-the-crossroads/, January 28, 2015.

${ }^{5}$ Ajmal Shams, "Afghanistan at the Crossroads," The Diplomat, http://thediplomat.com/2015/01/afghanistan-at-the-crossroads/, January 28, 2015.
} 
"to realize self-reliance in the transformation decade, in the face of likely reductions of donor assistance, more private investments and revenue-generating sources will be needed to trigger growth. Building infrastructure for regional integration trade and transit agreements, connectivity, cross-border investments will be a fundamental part of our national strategy. Public funds will have to be channeled to sectors with maximum potential for growth, revenue and employment. Aideffectiveness will have to be substantially improved."

Attempts made by both Afghan government and the international community to tackle the challenge of aid effectiveness have included the establishment of the ANDS and the National Priority Programs (NPPs); the signing in 2005 of Paris Declaration on Aid Effectiveness; and preparing public finance, procurement, and income tax laws. Despite these efforts, there is well-founded frustration at the pace of improvements both from Afghans and from the international community. Significant challenges remain, including establishing sustainable security and stability, strengthening the capacity of public institutions, fostering an environment in which the private sector can be developed, and reducing corruption.

The brief case studies contained in this report illuminate the positives and negatives associated with what the official overseeing U.S. reconstruction efforts has repeatedly called the most costly foreign-assistance initiative since the Marshall Plan. ${ }^{7}$

\section{Methodology}

\section{Purpose}

MEC's Terms of Reference authorize it to review the anti-corruption initiatives of the Afghan government and the international community. This review does not purport to provide a detailed analysis thousands of donor interventions that have been undertaken since the fall of the Taliban. But MEC's examination of a small, relatively diversified sample of projects, does illustrate several overarching themes.

\section{Assessing Success}

One critical theme was the lack of consensus about what truly constitutes a worthwhile, effective project, particularly given the enormous amounts of funding involved. It seems that many believed aid effectiveness was implied through alignment of programs with the ANDS or through the NPPs. Others believed that programs aligned with the Paris Declaration would imply de facto compliance with the general principles of aid effectiveness. ${ }^{8}$ The problem with these approaches is that none of themes, principles, high-level strategies, or plans developed since 2001 paid sufficient attention to the impact of aid on the supposed beneficiaries, nor did they really embody a true consensus among international and national stakeholders on deliverables and outcomes.

\footnotetext{
${ }^{6}$ Islamic Republic of Afghanistan, "Realizing Self Reliance: Commitments to Reform and New Partnership," London Conference, December 2014, page 5, paragraph 8.

${ }^{7}$ SIGAR, Special Inspector General, multiple statements, 2014-15.

${ }^{8}$ This report should not be considered a true "aid effectiveness" study because of the non-systematic selection of projects, the small sample of projects assessed, the differing amounts and quality of information available about said projects, and MEC's lack of access to several project sites.
} 
These shortcomings most likely had many causes. The security environment, including the underlying assumption that security would improve, undoubtedly compromised the ability to develop or implement monitoring and evaluation (M\&E) plans conducive to measuring true impact. In addition, the competing goals of short-term stabilization (often with military-driven objectives) and long-term development strategies mitigated against consensus on what constitutes aid effectiveness, given the significant differences in perception, timelines, goals of each approach.

The divergent strategies, lack of consensus, and unprecedented volume of projects compromised true donor coordination. However, many programs, both successful and unsuccessful in achieving their stated objectives, left behind resources that might still prove useful in planning and executing future projects. These include survey, assessment, and M\&E tools, as well as information, education, and communications materials that, given the prospect of diminishing resources, should at least be considered in planning future assistance programs. It would perhaps be a worthy exercise to gather these tools in an accessible format to ensure that they are available to current and future development practitioners. By doing so, the donor community and the Afghan government would be able to extract at least some benefit from even the most troubled programs.

\section{Perceptions}

The actual effectiveness of a foreign-assistance program is not necessarily equivalent to how its effectiveness is perceived by different audiences. Answering the question of whether or not a program is "effective," is a significant challenge in capacity-development projects. If a bridge is not built, and the program specifications specifically called for a bridge to be built, then the program plainly was not effective. But assessing whether human or institutional capacities have been developed and, if so, to a degree that would enable the program to be deemed "effective" is an order of magnitude more difficult.

Monitoring and evaluation agencies engaged in such endeavors bring with them their own biases and assumptions-and MEC is no different. In assessing some projects, much of the information upon which MEC relied was compiled by others, be they outside evaluators, project managers, Embassy officials, Afghan government employees, or other local nationals engaged with the project. They, too, bring with them to their reporting their own sets of preconceptions about what constitutes an "effective" initiative. Such constraints must be kept in mind when reviewing any effort to measure the worth of any project, including this one.

\section{Data Collection}

The data-collection methods employed in this study combined interviews, desk research, documentary analysis, and a limited number of site visits. MEC interviewed government officials representing 14 ministries, as well as numerous representatives from civil-society organizations (CSOs) and ordinary Afghan citizens. The interviews were structured so as to elicit information about the donor agencies' and Afghan government's roles in different aspects of aid administration. MEC also interviewed more than 30 individuals from various donors implementing partners (IPs). In these meetings, MEC explained the study's objectives and the nature of the information requested. The documents MEC received from these parties included strategic plans and policies, some independent evaluation reports, internal program reviews, case studies, MoUs, confirmation letters, and other legal documents. It is important to note, however, that unlike foreign (e.g., SIGAR) or Afghan law- 
enforcement and audit agencies, MEC lacks the ability to compel responses to our requests or to conduct independent investigations.

\section{Challenges}

MEC encountered a variety of challenges as it attempted to collect data. These included, inter alia:

\section{Security}

Security remained as a serious threat to data collection throughout the process. Taliban operations and political instability limited MEC's access to key informants, as well as to some GIRoA officials. Significantly, MEC's team was unable to travel to many provinces and districts to speak directly with the intended beneficiaries of many projects.

\section{Donor restrictions}

The quality and completeness of the information received differed from donor to donor, requiring MEC to attempt to obtain information from other sources and limiting our ability evaluate all of the projects using the same methodological tools. In some cases, a donor's laws, regulations, or policies mandated that certain information remain confidential, and MEC respected these boundaries.

\section{Standards of assessment-and their limitations}

The aid provided to Afghanistan by international community is often criticized for not having contributed to improvement of the lives of common people. This is of great concern, given the disproportionate role that foreign assistance plays in Afghanistan. While the Paris Declaration formed the framework for the standards employed herein, MEC recognizes its limitations and the fact that its requirements often had little relevance to the situation on the ground in Afghanistan. Consequently, MEC attempted to employ a hybrid approach, making allowances for the unique operating environment in which these projects were undertaken, though any approach, no matter its components, will have inherently subjective aspects that some readers may perceive as flawed.

\section{Project and Donor Selection}

Two major criteria were considered in the selection of key donors: the amount of aid funds contributed to Afghanistan since 2001 and the scope of development activities undertaken. MEC reviewed projects representing a variety of sectors for this report, including governance, economic development, rural aid, infrastructure, and capacity development. After consultations with key donors, MEC found that it was difficult for donors to provide the information on projects that were completed before 2010-a problem in and of itself. As a result, MEC chose to focus primarily, though not exclusively, on projects carried out during and after 2010.

\section{Corruption}


MEC's mandate is to monitor and evaluate anti-corruption measures taken by the government and by the international community. As part of this mandate, we strive to identify processes that increase vulnerabilities to corruption. But MEC operates under certain constraints that limit our ability to uncover particular acts of corruption and refer them for prosecution. MEC oftentimes simply lacks the resources to do so. Instead, in this report, MEC attempts to identify certain practices and trends that allow individuals to take advantage of well-intentioned programs for their own self-interested pecuniary motives. In approaching the problem of corruption from this oblique angle, MEC hopes to provide donors and the government with a sampling of some of the best-and some of the more problematic-aid practices and, therefore, contribute to the wider discussion on foreign-assistance programs.

\section{Factors Hindering Foreign-assistance Programs}

\section{Security}

The major effect of the still-precarious security situation is that it prevents the effective utilization of aid money. Insecurity limits access to project sites and imposes extra costs on aid programs that need to ensure the security of their staffs and physical assets. The high costs of security measures, such as armored vehicles, armed guards, cameras, barbed wire, and bunkers, place an extra burden on aid programs-money that could otherwise have been spent on actual development activities. The security environment also hampers the ability of organizations like MEC to conduct effective monitoring and evaluation of project sites.

\section{Economic Difficulties}

Recent economic difficulties have also adversely affected Afghanistan's development. On the macroeconomic front, MOF officials report that Afghanistan hopes bring in approximately $\$ 2.17$ billion this year from a variety of sources, including customs, mines, telecommunications licenses, and various registration fees-all of which are vulnerable to myriad forms of corruption. According to the MOF, 2014 government revenues were just over $\$ 2$ billion-about $25 \%$ lower than initial projections. Afghanistan's Gross Domestic Product (GDP) growth rate also slowed, decreasing from an estimated $14 \%$ in 2012 to about $1.5 \%$ in $2014 .^{9}$ These dire statistics have led to rising unemployment and stalled construction projects throughout the country.

The lack of funds flowing into the Afghan national treasury has prevented the upkeep of many foreign-assistance projects that were initially deemed successes. For example, the marked increase in the number of kilometers of paved roads since 2001 is often cited as an indication of the positive effect that foreign assistance has had on Afghanistan. But the World Bank now estimates that most of Afghanistan's roads are in poor shape and cannot be safely used by motor vehicles. ${ }^{10}$ In short, maintaining roads and highways has so far proven an unsustainable challenge for the government. This is a prime example of the need for the donor community and Afghan government to develop joint plans for operations and maintenance $(\mathrm{O} \& \mathrm{M})$ tasks that require funding from some source, be it international or

\footnotetext{
${ }^{9}$ World Bank, Afghanistan Data, GDP growth rate, http://data.worldbank.org/country/afghanistan, February 2015.

${ }^{10}$ SIGAR Quarterly Report to the U.S. Congress, July 2014, citing the World Bank's findings from mid-2014.
} 
domestic, after the "build" phase of certain projects has concluded. As one news story put it, in such cases, "Who fixes the potholes?"

Of the projects reviewed herein, their contribution to the economic health of Afghanistan could best be described as limited and/or localized. Of course, several of these projects were not designed to have direct economic effects, such as those rendering humanitarian assistance on an emergency basis. Others, such as Norway's prison-construction project, employed local contractors for certain aspects of the project, but the project's objectives lay elsewhere, making the any economic effects both transitory and minimal.

However, several projects discussed at greater length infra, including the Japanese-funded improvements to Bamyan airport; the agriculture projects financed by the EU and Japan; and U.S. Agency for International Development's (USAID) effort to improve Kabul Municipality's management processes arguably had a positive-if difficult to measure-effect on Afghanistan's economy. In particular, the Bamyan airport project and the U.K.'s efforts to develop provincial-budgeting capacities appear to show promise. But with large reductions in foreign assistance imminent, prompt action to address the persistent problems plaguing the moribund private sector are necessary for Afghanistan's long-term economic health.

\section{Underdeveloped Private Sector and Limited Foreign Investment}

The lack of a dynamic and well-developed private sector is another challenge facing Afghanistan. The underdeveloped private sector hinders Afghan ownership of the aid programs; causes higher costs, due to the involvement of international companies with high profit margins; and results in lower revenue generation for the central government. As one commentator recently noted, "in the absence of strong institutional and enforcement framework, the government was unable to collect taxes from an industry [construction] that otherwise could have contributed significantly to national revenues. Construction has been rife with tax evasion, mainly because of rampant corruption and the powerful political players with a stake in the industry." ${ }^{12}$ In addition, some donors to offer only small contracts to local construction companies (many of which are controlled by persons alleged to be involved in all manners of corruption), while reserving larger contracts for foreign companies.

While foreign companies are certainly no panacea when it comes to being free from corruption, they are often subject to their home nation's strict anti-bribery statutes that apply to their overseas operations. The U.S. Foreign Corrupt Practices Act, which entered into force in 1977, was one of the first such laws. More recently, the U.K. Bribery Act conferred similar authorities on British tribunals. While differing in the particulars, both of these laws, as well as similar provisions found more than 35 other countries, expose private-sector actors to prosecution in their home country for corrupt acts committed in other states. But while such laws incentivize transparent and honest business practices for companies operating in their shadow, they have the unintended consequence of making those exact same companies extremely reluctant to enter markets, such as Afghanistan, where the rule of law is weak. Thus, to attract significant investment from major multinational corporations, the Afghan government will have to reform its justice sector and continue to combat corruption.

\footnotetext{
${ }^{11}$ Christian Science Monitor, "Paved roads a positive legacy of Afghan war. But who fixes potholes?," Tom A. Peter, February 2 , 2015.

${ }^{12}$ Ajmal Shams, "Afghanistan at the Crossroads," The Diplomat, http://thediplomat.com/2015/01/afghanistan-at-the-crossroads/, January 2015.
} 


\section{Corruption}

Rampant institutional corruption prevents the government from taking ownership of aid programs. Despite efforts made by GIRoA and the donor community to mitigate corruption, it still stands as a major challenge that constrains the international community from channeling more of their aid funds through government's core budget.

A level of corruption exists, to some degree, in all aspects of aid administration-on the Afghan side and on the donor side-but contracting; the procurement of goods, materials, and services; staff recruitment; the selection of project beneficiaries; and picking project locations all remain exceedingly vulnerable to the influence of malign actors. In this report, MEC found that one of the most common problems involved efforts by powerful local actors to leverage their influence in order to take advantage of contracts flowing forth from foreignassistance programs.

Corruption must also be distinguished from waste, though an admittedly fine line separates the two. Wasted or misspent funds are not the same as corrupt acts. For example, a particular country's contracting guidelines may permit a large portion of project funds to be expended on salaries, vehicles, and plush living quarters for foreign consultants. But if such expenditures are permissible, then the problem is one of policy and prioritization and not-or at least not primarily-one of corruption. The work of the U.S. Special Inspector General for Afghanistan Reconstruction (SIGAR) is illustrative. Through its audit work, SIGAR has questioned more than $\$ 240$ million in reconstruction costs, but its work has led to the conviction of just 86 persons for crimes linked to U.S.-funded reconstruction projects in Afghanistan. ${ }^{13}$ This illustrates just how difficult it is to successfully build a criminal case against a foreign national working in a war zone.

\section{The Dubious Impact of Stabilization Projects}

While the stated purpose of stabilization projects is noble-the rapid provision of services to local populations in the hopes of reducing violence in that area-the rationale underlying this premise and, most especially, the execution of such projects in the field, is questionable. Military priorities often clashed with those of development professionals, resulting in ad hoc working arrangements of dubious effectiveness. These circumstances are most apparent in so-called "stabilization" projects, which were often under the direction of that quintessential military-civilian hybrid, the Provincial Reconstruction Team (PRT).

First used in Iraq, the PRTs were supposed to expand the coalition's footprint into the provinces and ensure that reconstruction funds reached beyond the major cities and towns. Operationally, however, PRTs often undermined local Afghan authorities and sometimes even duplicated work performed by other foreign agencies. PRT record keeping was also poor, as evidenced by a 2011 SIGAR audit of the PRT in Laghman province that categorized

\footnotetext{
${ }^{13}$ As this report's repeated references to SIGAR's aggressive and effective oversight work make eminently clear, the purpose behind citing these statistics is not to diminish SIGAR's investigative work, but merely to point out that, in most Western countries, such as the United States, the evidentiary hurdles are much higher when the case is criminal in nature. In short, identifying ill-conceived and poorly executed projects is a fundamentally different task from the more difficult job of building a criminal case based on evidence collected in a war zone related to activities that often occurred several years ago.
} 
as "at risk or having questionable outcomes" projects valued at $\$ 49.2$ million out of the $\$ 53$ million available in a specific pool of funds. ${ }^{14}$

USAID also played a major role in stabilization programs. According to one 2014 article, USAID obligated more than \$1 billion for stabilization projects from 2003 to 2012 . One such project, the Local Government and Community Development (LGCD) Programme cost more than $\$ 400$ million, but a 2012 SIGAR audit found that more than half of the Programme's expenditures went to salaries and security (though SIGAR did note that USAID's management of the project improved over time). Further, USAID's Inspector General described the project's overall success as "highly questionable." While the LCGD Programme is not a subject of this report, secondary sources illustrate how its shortcomings serve as a proxy for the problems inherent in many other stabilization programs. ${ }^{15}$

\section{“Overhead" Expenses}

The LCGD Programme's difficulties in controlling salaries, security expenditures, and other overhead costs are neither unique to it, nor unique to stabilization programs. To the contrary, overhead expenses, broadly defined, have been and remain a serious issue for most foreignassistance projects in Afghanistan. Security issues make projects in Afghanistan, and other unstable countries, vulnerable to escalating costs, especially when foreign personnel are involved in the implementation process. Not only do such foreign "experts" stand out from the local population, and therefore require special-and costly-security accommodations, they often demand much higher salaries to travel to conflict zones. To take one isolated example, many U.S civilian government employees working in Afghanistan (and Iraq) receive their base salary, plus $70 \%$ in combined danger-pay and post-differential allowances, plus any overtime pay that their agency permits them to accrue. To match this generous package and retain their best employees, many contracting companies boost salaries for expatriates working in these countries by a similar amount, feeding an ever-escalating spiral of contract costs.

But the issue is not a straightforward one, for absent such overhead expenses, many projects would never be implemented in unstable countries, depriving residents of whatever benefits they may deliver. The issue of overhead costs and their effect on foreign-assistance programs was the subject of a much-cited 2008 paper by renowned development economist William Easterly (with Tobias Pftuze). Their findings illustrate the difficulties in drawing definitive conclusions about overhead costs. As an initial matter, the authors were forced to develop their own nine-part definition of "operating costs," because no universally agreedupon criteria existed. Moreover, the authors found it difficult to obtain transparent data from aid agencies on these expenses, qualifying their findings as "undeniably shaky" and subject to "tremendous variation." 16

Despite these caveats, the authors concluded that two of the countries covered by this report-Japan and Norway_are among the top four when it comes to exercising effective

\footnotetext{
${ }^{14}$ The $\$ 53$ million funding pool consisted of Commander's Emergency Response Program funds. Ashley Jackson, "What have we learned about stabilization programs in Afghanistan? Not much," Foreign Policy website, http://foreignpolicy.com/2013/05/15/what-have-we-learned-about-stabilization-in-afghanistan-not-much/, May 2013. ${ }^{15}$ SIGAR Audit 12-08, www.sigar.mil, April 2012

${ }^{16}$ W. Easterly and T. Pftuze, "Where Does the Money Go? Best and Worst Practices in Foreign Aid," Journal of Economic Perspectives-Volume 22, Number 2, http://dri.as.nyu.edu/docs/CP/2313/Where Does Money Go.pdf, Spring 2008.
} 
controls of overhead costs. ${ }^{17}$ In response to MEC's request for information about overhead costs, the Royal Norwegian Embassy (RNE) in Kabul stated that, in general, overhead expenses are capped at $7 \%$, subject to certain exceptions. ${ }^{18}$ But with regard to the three projects covered by this report, the RNE stated to MEC via an April 2015 email that the relevant records were in the basement of the Ministry of Foreign Affairs in Oslo and, therefore, not easily accessible. ${ }^{19}$ In response to a similar query, the Japanese International Cooperation Agency (JICA) stated that the projects covered in this report are classified as "grant aid," with overhead costs largely governed by the Agency Agreement signed between Afghanistan and UN Office for Project Services (UNOPS). ${ }^{20}$ The EU also applies distinct criteria when calculating overhead costs, which are further discussed in the sections assessing the three EU projects MEC examined. Of the agencies ${ }^{21}$ whose projects are included in this report, the most comprehensive information about overhead costs came from the U.K.'s Department for International Development (DFID). ${ }^{22}$ Details of DFID's overhead costs for its projects are provided in the relevant sections below, but, in general, such costs amounted to at least one-quarter to one-third of project costs.

\section{Largely Off-Budget Support}

Afghanistan should exercise effective leadership over its development policies and strategies to ensure that the needs of the poor Afghans are met by these programs. A gradual increase in the amount of aid funds invested through the GIRoA's core budget, proportionate to a gradual increase in its absorptive capacity, should be considered. But there persists a lack of government capacity and well-founded doubts within the donor community about the country's management and procurement systems. Therefore, building capacity through technical cooperation that is aligned with the country's needs remains a priority. That a large amount of aid is still channeled through off-budget programs is perhaps the most salient indication of the weakness of government institutions. Where possible, donors should continue to make efforts to employ existing government capacities, field testing them to expose their weaknesses, and suggesting practical remedies to fill these existing capacity gaps.

\section{Lack of Indigenous Capacity}

As noted, the lack of capacity is one of the major challenges Afghanistan is faced with in asserting sovereign control over development programs. In most Afghan ministries, it can be

\footnotetext{
${ }^{17}$ W. Easterly and T. Pftuze, "Where Does the Money Go? Best and Worst Practices in Foreign Aid," Journal of Economic Perspectives-Volume 22, Number 2, http://dri.as.nyu.edu/docs/CP/2313/Where_Does_Money_Go.pdf, Spring 2008.

${ }^{18}$ RNE - Kabul, Head of Development, emails to MEC, April 27, 2015.

${ }^{19}$ RNE - Kabul, Head of Development, emails to MEC, April 27, 2015. The RNE also provided MEC with a copy of their general cost guidelines for such projects.

20 JICA's response to MEC states, in pertinent part, that the three projects addressed by MEC in this report: "are classified "Grant Aid for Conflict Prevention and Peace building" in the lineup of Japanese grant aid schemes. (http://www.jica.go.jp/english/publications/reports/annual/2013/c8h0vm00008m8edo-att/49.pdf) And we implement "Grant Aid for Conflict Prevention and Peace building" projects based on the procurement guidelines of Japan's grant aid (Type I -C) in spite of these projects are based on construction. (http://www.jica.go.jp/activities/schemes/grant aid/quideline/ku57pq00000sby3vatt/02_e.pdf) The recipient country's implementation organizations (KM, ACAA, etc.) concluded the agent agreement (A/A) between UNOPS which supplies or provides the products and services for the Projects. And as for overhead according to UNOPS definition is management fee, and they are 7\%." JICA email to MEC, April 29, 2015.

${ }^{21}$ USAID provided its general guidelines about "indirect costs," USAID email to MEC, May 2015; and other USAID-provided documents on project costs, 2014. As of early May 2015, the EU had not provided details on overhead costs for their projects included in this report.

${ }^{22}$ DFID is one of MEC's two primary donors.
} 
a challenge to find a sufficient number of Afghan counterparts who are true technical experts. Therefore, donors often take the lead in the project-design process. Without effective human and systemic capacities within government institutions, Afghanistan will remain unable to manage effectively assistance provided by donor nations.

The sub-national level is even less developed. Internal problems exist between the central and provincial levels. For example, the provincial line departments are often not able to feed information into the budgeting cycle, although efforts continue to fill the coordination and partnership gap between these two layers of GIRoA. Sub-national actors also suffer from a lack of coordination at all levels (i.e. between different authorities in different provinces and between provincial and district authorities in the same province), creating overlapping responsibilities and muddled lines of communication. If the capacities of the Afghan government at the provincial and local levels develop further, the government as a whole will be more capable of asserting its autonomy and managing its budget effectively.

\section{Centralized Budget Planning}

Decentralized budget planning and the participation of local governments in the design and implementation of development projects is essential to improving aid effectiveness. Planning at the sub-national level remains largely ineffective, and plans generated in the provinces are usually not integrated into national programs, the national budget, or off-budget aid projects. Among the factors contributing to this are the poorly resourced and under-staffed nature of provincial and district bodies; their limited decision-making authority; the ambiguous nature of the rules and regulations governing provincial powers; unclear lines of responsibilities of subnational level; and the lack of capacity many provincial entities.

\section{Lack of Inter-Ministerial Coordination}

Coordination among line ministries is also challenging. Each ministry wants to maximize its autonomy, rather than showing common achievements by working together with other ministries. In particular, politically ambitious ministers often do not want to share credit for their accomplishments with potential rivals.

\section{Political Complexity of Aid Delivery}

There is increasing international recognition that the present methods of aid delivery are overly technocratic and fail to address political complexities, or to demand partnerships between the donors and government that are more than bureaucratic relationships. The lack of substantive, equal partnerships between some donors and IPs and GIRoA institutions served to isolate the government from updated information about many projects, depriving it of essential knowledge, transforming it into a passive recipient of external aid, and weakening its ability to replicate useful projects in the future.

\section{Turnover of Personnel in Afghan Ministries}

Many ministries are unable to attract and retain qualified employees. This problem is exacerbated by the poaching of qualified Afghan staff by international organizations and NGOs, as these bodies usually offer qualified Afghans better salaries than do government agencies. An improved compensation structure and significant improvements in the 
prevailing work environment-including a sustained commitment to rooting out corruption, ending impunity, and protecting whistleblowers—could lessen employee turnover.

\section{IV.Countries/Agencies Featured}

\section{United States: USAID}

The United States has been the largest donor to Afghanistan since 2001. Its primary conduit for non-security assistance is USAID. From 2002 to 2013, USAID disbursed $\$ 13$ billion in funds to Afghanistan, with approximately $84 \%$ being delivered through off-budget mechanisms. ${ }^{23}$ USAID Afghanistan uses several types of off-budget vehicles to deliver assistance through its IPs, including contracts, grants, and operating agreements. ${ }^{24}$ For this report, MEC reviewed two U.S.-funded projects.

\section{U.S. Oversight of its Afghanistan Reconstruction Program}

As the largest donor to the reconstruction effort, the United States also sponsors the most prominent oversight agency-the Office of the Special Inspector General for Afghanistan Reconstruction. Formed by former President Bush in 2008, SIGAR was handicapped in its first years by this late start. However, of late, it has found its footing, and while its jurisdiction is limited to the oversight of U.S. reconstruction funding, it interprets this mandate broadly, enabling it to provide valuable insights on everything from the training of the Afghan National Police (ANP) to U.S.-financed educational initiatives. In a May 2015 presentation, the Inspector General summarized some of SIGAR's most significant findings, including:

- the fact that about $\$ 15$ billion more in U.S. reconstruction funds have been appropriated by Congress, but not yet expended;

- the $\$ 8.4$ billion spent by the United States on counter-narcotics programs has been largely ineffective, with opium production at or near record highs;

- that data on increases in life expectancy-long touted as a major success storyare open to question, with USAID claiming Afghan life expectancy at 62 years; the Central Intelligence Agency countering with an estimate of about 50 years; and the UN Population Division, the U.S. Census Bureau, and the World Health Organization also provide lower estimates than USAID;

- that while USAID has disbursed more than $\$ 768$ million for education programs in Afghanistan, and the Afghan Ministry of Education reported 8.35 million students in 2014, 1.55 million students were categorized as "absent," and the Ministry counts as "enrolled" students who have been absent for up to three years, leading one USAID official to confide to SIGAR that the real number of students actually attending classes may be closer to 4 million;

- that no reliable reporting exists on the educational credentials of many teachers, nor on the contents of the curricula offered in many schools; and

- that while the U.S. has provided more than $\$ 16$ billion for the ANP since 2002, there "is still no assurance that personnel and payroll data are accurate," as paper-based record keeping and rampant corruption preclude an accurate assessment of the ANP's actual force strength.

Source: SIGAR, "Afghan Reconstruction: Fact vs. Fantasy," Prepared Remarks of IG John Sopko, www.sigar.mil, May 5, 2015.

\footnotetext{
${ }^{23}$ USAID, information provided in response to a MEC request, January 2015. Note that USAID data referenced above refers only to funds disbursed.

${ }^{24}$ According to the information received by MEC, approximately $83 \%$ of USAID's current programs are aligned with Afghanistan's NPPs.
} 


\section{United Kingdom: DFID}

DFID is the fourth largest donor after the United States, Japan, and the European Union. Among the sectors targeted by DFID assistance programs are governance, security, wealth creation, and education. During the period from 2002 to 2013 , DFID had disbursed $£ 1.3$ billion (approximately $\$ 1.97$ billion ${ }^{25}$ ), about $56.7 \%$ of which was provided through off-budget vehicles. ${ }^{26}$ This report looked at three DFID projects.

\section{European Union}

The EU remains one of the major donors of development and humanitarian assistance to Afghanistan. From 2002 to 2011, the EU contributed approximately $€ 2.5$ billion $^{27}$ (or about $\$ 2.9$ billion $^{28}$ ) to Afghanistan. For $2014,36 \%$ of the $\$ 244.12$ million that the EU committed for Afghan assistance was provided through off-budget implementing modalities managed directly by the EU. ${ }^{29}$ MEC assessed three EU-funded projects for this report.

\section{Japan: JICA}

Japan is also one of the largest donors to Afghanistan, and it dispatches its assistance primarily through JICA. From 2002 to 2013, Japan disbursed approximately $\$ 5.4$ billion in financial assistance to Afghanistan. JICA primarily focuses on poverty eradication, education, healthcare, water projects, media support, and the transportation sector. MEC examined three JICA-funded projects for this report.

\section{Norway}

Norway has been one of the largest donors to Afghanistan since 2002. According to the MOF, from 2002 to 2013 Norway disbursed about \$1.2 billion in financial assistance to Afghanistan. Norway focuses its efforts on programs aimed at developing good governance, education, and rural development. Human rights, gender equity, and combating corruption are other focus areas for Norwegian assistance. Norwegian aid is channeled through the UN, the World Bank, various trust funds, and international voluntary organizations. MEC reviewed three Norwegian-funded projects for this report.

\footnotetext{
${ }^{25}$ Pounds converted to dollars using the market exchange rate, as of early 2015 .

${ }^{26}$ Information provided by DFID - Afghanistan, April 2014.

${ }^{27}$ EU, www.eeas.europa.eu.

${ }_{28}$ As noted supra, all figures are approximate and based on the best available data received from the donor agencies as of late 2014. Because some information was received in currencies other than the U.S. dollar, exchange rate fluctuations may also affect the estimated costs of certain projects. When converting other currencies to U.S. dollars, January 2015 rates were used.

${ }^{29}$ EU Delegation to Afghanistan, information provided via email in response to MEC request, January 25, 2015.
} 


\title{
V. Projects Reviewed by Sector
}

\section{Stabilization}

\author{
USAID: Rule of Law Stabilization Program - Informal Component (RLS-I) \\ Location: $\quad$ Southern, eastern, and northern provinces \\ Dates: $\quad$ July 2012 - January 2014 \\ Estimated cost: $\quad \$ 15.65$ million \\ IP: $\quad$ Checchi \& Company Consulting
}

The Rule of Law Stabilization Program - Informal Justice Sector Component (RLS-I) supported the traditional justice sector and worked directly with traditional dispute-resolution institutions (TDR) and local government and religious stakeholders to foster linkages between the formal and the traditional justice systems. The overall objective of the RLS-I Program was the strengthening of Afghanistan's traditional justice sector, with the aim of bringing it into greater alignment with the Afghan Constitution and safeguarding the rights of individuals, particularly women. Many TDR mechanisms use traditional beliefs and customary practices to resolve disputes, but these methods sometimes violate the rights of individuals. RLS-I attempted to address this issue and, through a series of trainings and outreach tools, to reduce the likelihood of TDR decisions violating the rights of Afghans.

The Ministry of Justice (Huqooq Department), the Ministry of Borders and Tribal Affairs, and Nangarhar University (Law and Sharia Faculties) served as USAID's primary Afghan interlocutors for this project. Prior to design phase, consultations took place with officials from all three institutions to ensure that their input was incorporated into the project's design. In addition, the lessons identified at the end of each phase of RLS-I were incorporated into the design of the next phase.

\section{Stabilization is not development}

The RLS-I program was similar to legal-empowerment programs that have been used in a range of environments, including post-conflict and complex-emergency settings. For the most part, however, these types of programs are typically motivated by development principles, rather than stabilization goals, and therefore have typically longer-timelines. Trainings of this type, as both internal and external evaluations have noted, are less effective when given over compressed time periods. The correlation between time and didactic benefits are well established in rule-of-law training programs, and perhaps, should have been contemplated in the program design. Again, the over-emphasis on stabilization objectives versus broader development goals dictated the timelines and, ultimately, may have undermined what, at minimum, could have been a model community-based rule-of-law program that might have been used to develop innovative long-term justice approaches for Afghanistan.

Knowledge and the application of knowledge are two different issues. Both internal and external evaluations of the RLS-I program suggest some positive effects from the training 
sessions, which did appear to increase scores based on pre-test and post-test grades. The extent of that causal relationship is unclear, however, and for purposes of determining future funding for similarly projects, it would have to be explored more rigorously.

What is conspicuously absent from both evaluations, though, is a significant discussion of the stabilizing effect of the program. Many stabilizations programs in Afghanistan over the past decade were immune to, or managed to escape, this scrutiny. The most serious attempt to measure the impact of stabilization programs is USAID's MISTI (Measuring Impacts of Stabilization Initiatives) project. Early results from this initiative suggest that these types of programs had little to no affect in bringing about sustainable stability in the areas in which they were conducted, and it would be hard to argue that RLS-I was any different.

\section{Strategic flaws hamper justice-sector programs}

RLS-I was also undermined by a flawed strategic objective that was common to many civilian and military rule-of-law initiatives at the time: the desire to bring the formal and informal systems into a productive partnership. This objective, again largely driven by stabilization goals, was based on the assumption that state-justice stakeholders were committed to the fair administration of justice, would uphold the increasingly high standards set by the international community, and would be active participants in promoting such linkages. This strategy was destined for failure, even in relatively stable environments, due in large part to high levels of real and perceived corruption in formal justice institutions, such as the Attorney General's Office. To their credit, both Checchi and the independent evaluator acknowledge these difficulties in their reporting.

RLS-I was, at minimum, a worthy experiment and an honest attempt to address a dimension of justice in Afghanistan that was largely underserved by the donor community at a time when most justice initiatives were focused on the formal system. As a consequence, the impact of this program must be viewed beyond its proposed objectives to include insights gained that could be used to inform future initiatives. However, if the lessons learned during the implementation of the RLS-I program are not built upon, then all programs, except for those with definitive end results (such as infrastructure), may be considered, to some degree at least, to have been failures.

\section{Project avoided creating new institutions dependent on foreign funds}

On the positive side of the ledger, RLS-I avoided creating dependent institutions, such as newly created councils, and limited material assistance. This practice is one that should be emulated by other donors working on similar projects. For example, facilities provided for Jirga halls incurred no continuing costs. Use of government facilities also fostered modest state-TDR linkages and avoided rental fees. RLS-I also explored the potential for ongoing sustainable support to TDR practitioners by Afghan institutions, but no evidence was available as to whether this was achieved. 


\section{Stabilization and CERP: A Flawed Concept Produces Questionable Results}

As of January 2015, the United States had committed approximately $\$ 3.68$ billion in Commander's Emergency Response Program (CERP) funds. The majority of CERP projects were administered by the military and designed to provide rapid results, contributing to the stabilization of the immediate geographic area. But of the approximately $\$ 2.2$ billion disbursed by the U.S. Department of Defense (DoD), only $\$ 890$ million $(40 \%)$ could be accounted for by SIGAR auditors because of DoD's poor financial management processes. In response, U.S. military commanders conceded the report was accurate, but said it did not account for CERP's role in counterinsurgency (COIN) strategies, illustrating yet again the fundamentally different standards by which stabilization/COIN programs were judged.

This focus on immediacy-often at the expense of planning or coordination with other ongoing efforts in the battlespace-led to the funding of many questionable projects. Furthermore, the emphasis on immediate results undermined the entire concept of sustainability, and many CERP projects left little or no legacy once U.S. forces withdrew from the area. More perniciously, commanders in the field who did not expend their allotment of CERP funds before the conclusion of their tour would, in some cases, have this fact counted against them in their subsequent performance evaluation.

CERP was designed to fund primarily small-scale projects. While large-scale projects accounted for a small proportion of the total number of projects, they consumed a vast amount of CERP funds. But large-scale projects posed increased risks for CERP, because they required several years for completion and were often administered by managers who were trained to implement only small-scale projects. In fact, according to a SIGAR, the U.S. military could not identify the number of total CERP projects undertaken prior to Fiscal Year 2009.

With regard to categorizing the types of projects that CERP financed, the transportation sector led the way, but a majority of the more than 10,000 CERP projects could only be characterized as "Unknown." In addition, more than 4,800 other CERP projects were either cancelled or described as failures during those 10 years. Two of Afghanistan's most unstable provinces, Helmand and Kandahar, received the largest amount of CERP funds between 2004 and 2014. Taken as a whole, these findings strongly suggest that, while commanders in the field should have some discretionary funds at their disposal, they are, by definition, not development professionals and the current security situation in Helmand and Kandahar implies that rapid-impact stabilization projects often failed to achieve their desired effects. 


\title{
2. Administrative Capacity Development
}

\author{
USAID: Kabul City Initiative (KCl) \\ Location: Kabul City \\ Dates: $\quad$ October 2010 - September 2013 \\ Cost: $\quad \$ 44.63$ million \\ IP: $\quad$ Association for Rural Development, Inc. (ARD) and Tetra Tech
}

The Kabul City Initiative $(\mathrm{KCl})$ provided technical and material support to the Kabul Municipality (KM). The three-year project worked in close partnership with Kabul's mayor and municipal staff to enhance KM's administrative and management functions. According to USAID, $\mathrm{KCl}$ aimed to provide effective, responsive service delivery through $\mathrm{KM}$ departments and offices, and to improve the long-term sustainability and financial viability of Kabul Municipality.

\section{Human-capital Development}

Human-capital development was one of the program's major objectives. The $\mathrm{KCl}$ capacitydevelopment programs were demand-driven, based on the results of needs assessment and a three-year master plan. The training programs included financial reporting, basic computer skills, internal auditing, program budgeting, basic accounting, digitization of property documents, revenue collection, financial management, advanced and intermediate accounting, and various train-the-trainers programs. Participants from the majority of KM's departments and sections attended one or more of these classes.

\section{Afghan counterpart involved throughout the life of the project}

$\mathrm{KCl}$ attempted to involve its government counterpart in different aspects of projectadministration process, such as developing priorities, designing programs, planning their implementation, and monitoring the overall program's progress. This made $\mathrm{KCl}$ different from some other projects addressed in this report, as it appears to have utilized existing KM human capacities, where possible.

The $\mathrm{KCl}$ project is an example of a functional partnership between the USAID and a major Afghan institution. $\mathrm{KM}$ assigned a number of senior officials to work alongside $\mathrm{KCl}$ staff and also to serve as members of the $\mathrm{KCl}$ oversight team. The project also helped to stand-up the mayor's biweekly donor-coordination meeting, which served as a mechanism to gain final KM approval of $\mathrm{KCl}$ projects.

\section{Public opinion solicited}

The signing of a MoU between USAID/KCI and $\mathrm{KM}$ was the first step taken to ensure accountability. The MoU contained mutual commitments agreed to among the partners. $\mathrm{KCl}$ and $\mathrm{KM}$ also made extensive efforts to enhance public participation and awareness of the $\mathrm{KCl}$, its objectives, achievements, costs, and benefits. This was accomplished through different public events, such as gatherings at project sites, ribbon cuttings, and graduation 
ceremonies. Public opinion of the $\mathrm{KCl}$ was also actively sought throughout the process via surveys, meetings, and other methods. More than 200 media events were conducted to provide increased transparency and better public interaction with the municipal government.

Construction of a Public Information and Resource Center (PIRC) was another measure aimed at preventing corruption and increasing citizens' access to information on municipal businesses and services. The PIRC provided a physical and electronic access point for the citizens of Kabul to obtain information, get access to KM offices easily, and conduct business with the municipality. Providing the Afghan people with tangible evidence that international assistance is being put to good use in a manner that will yield measurable improvements to the quality of life is essential to ensuring the development of a trust-based relationship between the new government, the international community, and the average citizen. These outreach efforts represented an attempt by the project's partners to involve the community in its implementation-a practice too often ignored by other donors and implementing partners.

\section{Increased revenue put to uncertain use}

It could also be argued that it improved revenue collection for the city. In the first year of the project, $\mathrm{KCl}$ analyzed current and potential legal sources of revenue, producing a three-year revenue-improvement plan, and helped the KM in preparing a Revenue Improvement Action Plan.

According to unaudited figures obtained by MEC in April 2015, revenue for KM did increase by approximately $18.9 \%$ from 2011 to 2013 . But these gains, while tangible, do not take into account population growth or budget expenditures. Further, there is no quantifiable evidence that this growth was a result of the $\mathrm{KCl}$ project. In addition, there are no reliable reports showing how these funds were used to fund $\mathrm{KM}$ operations, raising serious questions about the skimming of public funds by officials. In and of itself, revenue growth must be a priority for the Afghan government, but oversight agencies such as the Supreme Audit Office and the Attorney General's Office must improve their capacity to track and monitor municipal expenditures. As one senior $\mathrm{KM}$ official remarked to MEC, better enforcement of the tax laws, and vigorous pursuit of those who would evade them, is essential to improving the municipal government's capacity to deliver services.

\section{Sustainability remains questionable}

USAID and TetraTech ARD, in cooperation with $\mathrm{KM}$, attempted to build the essential capacities of individuals, teams, and departments, with the goal of having these persons and institutions carry out post-project O\&M. However, no evidence was provided to MEC describing in detail how post-project O\&M activities will be financed until KM is fully selfsufficient. This places at risk whatever gains the project was able to achieve. With Afghan government's recent budget difficulties, it remains questionable whether the achievements of relatively successful projects can be sustained over the long term.

\section{DFID: Strengthening Provincial Administration and Delivery (SPAD)}

Location: Helmand, Bamyan, and Uruzgan provinces

Date: $\quad$ 2010-2015

Cost: $\quad \$ 34.13$ million

IP: $\quad$ IDLG and Adam Smith International 
SPAD is the first DFID program funded through the GIRoA core budget, which, in and of itself, is a notable achievement. As per SPAD's design, funds allocated and disbursed at the provincial and districts levels are managed by provincial authorities. SPAD targets five provinces (Helmand, Uruzgan, Bamyan, Kabul, and Kapisa) and approximately 14 ministries through their Provincial Line Departments (PLDs). SPAD's overall objectives include improving the delivery of public services, introducing and practicing a model of de-centralized budget planning, and strengthening sub-national governance.

\section{On-budget assistance: a step toward self-reliance}

The MOF is the key government interlocutor for this project, while they IDLG has implemented the project through the SPAD Team (SST). An MoU was signed by MOF, DFID and DANIDA to govern SPAD funding, while the SST funding was governed by another MoU singed by MOF, DFID, and IDLG. The SST is recruited by and report to IDLG. It is responsible for supporting provincial, district, and municipal officials. DFID separately contracted (off budget) with ASI to advise and support the SST.

SPAD has been funded through GIRoA's operating budget, and its budget administration uses the relevant Afghan laws to govern it. The IDLG supports provincial and district governor's offices and PCs to coordinate planning and implementation of SPAD processes and activities. The planning process is coordinated through the provincial governors and brings together key actors from provincial-level directorates and the PCs to prioritize and agree on SPAD-funded activities.

The SST has developed its own financial tracking system to track how much money goes to each district, but the project still only has limited ability to track each particular activity's cost and status. Despite these shortcomings, SPAD is a unique aid program in terms of the GIRoA ownership over most of aspects of its administration process, including an Afghanowned technical approach applied for its implementation. The SPAD administration approach could potentially be utilized as a model for MOF's provincial-budgeting policy.

\section{Decentralization remains a major challenge}

The SPAD program is fully in line with Afghanistan's NPPs, utilizing government systems and processes. Procurement for on-budget support follows GIRoA regulations, but SPAD introduced additional safeguards, such as regular visits to provincial offices and the introduction of a technical committee to monitor purchases. But communication between Kabul and the provinces about the project's progress and objectives remains weak, and DFID is only able to exercise a limited amount of oversight the SST's actions. This dilemma encapsulates the greatest strength and most profound weakness of this project-utilizing a de-centralized structure that empowers local Afghans and minimizes the role of the donor oversight. DFID acknowledges that one of SPAD's greatest challenges is weighing the need for greater Afghan self-reliance against the potential for increased vulnerabilities to corruption, inefficiency, and waste.

\section{Implementation and sustainability}


SPAD is implemented by an Afghan technical team, which is recruited by IDLG and supported by the project, and by an international technical assistance team of three ASIrecruited advisors.

The long-term sustainability of the project depends on whether funds will be allocated for the project's expansion to other provinces, whether the implementers remain with the government after the funding ends, whether the MoF and IDLG will act upon their commitments for post-project activities, and whether there is adequate human and institutional capacities created within IDLG by SPAD to contribute to the independent expansion of this model to rest of Afghanistan.

\section{Overhead costs}

In its March 2012 Annual Review of this project, DFID reported that about one-third of project funds had been spent on organizational and management costs, such as salaries. In its March 2014 Annual Review, DFID again cited "high consultancy costs caused by the security context and the limited pool of consultants willing to work in Afghanistan" as a primary driver of project costs. DFID's 2014 Annual Review also provided this detailed look at project expenses for Solar Year 1392: ${ }^{30}$

\section{SPAD activities - by budget}

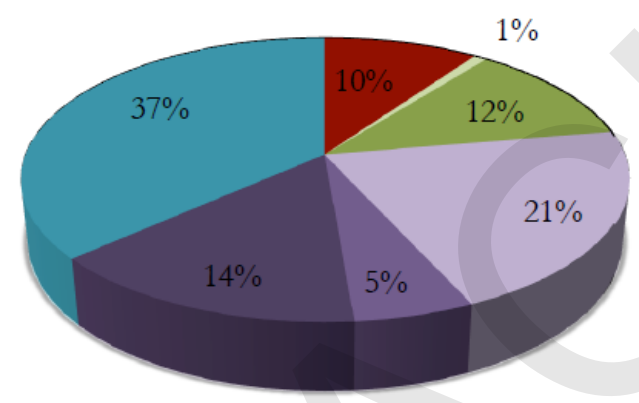

- Hardship allowance

- Office equipment

- Operations cost

Infrastructure construction
Office supplies

Capacity development

- Infrastructure maintenance

\section{Gender Issues}

\section{DFID: Increasing Women's Political Participation and Dialogue Opportunities} (IWPPDO)

Location: Kabul province (primarily)

Date: 2013-2015

Cost: $\quad \$ 7.68$ million $^{31}$

IP: $\quad$ The Asia Foundation (TAF)

\footnotetext{
${ }^{30}$ Information on all DFID projects is readily accessible via their website: http://devtracker.dfid.gov.uk/.

${ }^{31}$ All figures are approximate and based on the best available data received from the donor agencies, as of late 2014. Because some information was received in currencies other than the U.S. dollar, exchange rate fluctuations may affect the estimated cost of certain projects.
} 
This project is intended to strengthen women's political participation by building the capacity of female candidates and supporting formal and informal dialogues to help broaden support for women's political participation during the 2014 presidential and the 2015 parliamentary elections. $^{32}$

\section{MOWA's limited capacity precludes it from playing a more active role}

According to officials interviewed by MEC, some MOWA officials reported that the Ministry has limited information about the details of this project. MOWA's relative lack of involvement in the implementation of this project results, in part, from its lack of capacity. It does not have a robust M\&E department, adequate human capacity, nor the resources to fulfill such functions.

\section{Some overlap with similar programs}

As the donor, DFID has participated in frequent meetings with other aid agencies, managing agents, and government agencies in an attempt to prevent the duplication of effort with programs undertaken by other donors. That said, the training component of this project overlaps with a similar USAID-funded project implemented by NDI. There is also some overlap with a Canadian-supported project, indicating a need to improve coordination among donors active in this sector.

\section{Use of direct-feedback mechanism provides participants a greater voice}

In addition to attending the usual slate of donor-coordination meetings, DFID also employs a direct-feedback mechanism to collect the views of different stakeholders, including female provincial-council candidates, religious leaders, and presidential candidates' campaign officials. As with the mechanisms established by the $\mathrm{KCl}$ project, these initiatives are worthy of emulation because they provide the Afghan people with an enhanced say in donor activities.

\section{The challenge of measuring training results}

As of late 2014, TAF has undertaken in-person and telephone interviews with $60 \%$ of the participants. Pre- and post-training tests were also conducted by local implementers. However, at the moment, there is no mechanism for measuring the increase in participants' actual capacities.

\section{Use of a quasi-PIU calls into question sustainability}

TAF implements this project, in conjunction with the IEC. The required staff for this project is recruited and supported by TAF and functions similar to a Project Implementation Unit (PIU). It is unclear whether the project staff will leave the IEC after donor support draws to a close. This potential loss of skilled personnel stands as yet another example of the challenge faced by the financially strapped Afghan government after donor funds are reduced. The IEC apparently lacks a formal plan to continue this program after foreign support ceases, which suggests that the program's achievements may be, at best, ephemeral.

\footnotetext{
${ }^{32}$ As of May 2015, limited information about this project's budget was available on DFID's website, hence the impact of overhead costs cannot be assessed.
} 


\title{
4. Security and Law Enforcement
}

\section{DFID: Strategic Support to Afghan Ministry of Interior (SSMI)}

Location: Kabul, Balkh, and Samangan provinces

Date: $\quad$ 2011-2015

Cost: $\quad \$ 16.86$ million

Partners: Coffey International

This program was undertaken at the request of the Minister of Interior (MOI) who asked the U.K. for support in July 2010 in improving its strategic planning, personnel management, policies, business processes, and human-rights training.

\section{Questionable value delivered by outside advisors}

The project is implemented by international and national advisors, who cannot be considered as assets to the $\mathrm{MOI}$ over the long term. According to officials interviewed by MEC, the MOI is not actively engaged in other aspects of the project-implementation process, limiting its ability to obtain essential knowledge about the day-to-day affairs of the project and raising concerns about the project's sustainability and effectiveness. While it directly targets a number of $\mathrm{MOI}$ officials and departments, the project has not formed a team within $\mathrm{MOI}$ to plan for future such endeavors once DFID terminates its support.

According to information gathered by MEC, the project has resulted to some modest improvements in MOl's capacities in the targeted areas, but several officials within MOl's leadership contend that the Ministry did not receive adequate support to institutionalize practical changes to remedy these deficiencies on a permanent basis.

\section{Overhead costs}

DFID's 2014 Annual Review of this project reported that, management and security costs combined to total up to $29 \%$ of total project costs. The Review found that:

\begin{abstract}
"[a]s this is a technical assistance project, the key cost drivers continue to be staff consultancy fees and associated costs (security and life support). Coffey International has signed up to DFID's Statement of Priorities and Expectations for suppliers. Efforts to drive down project management fees and use economies of scale with other Coffey projects to reduce accommodation and life support expenses have helped reduce costs. Project management costs have continued to represent around $4 \%$ of total expenditure over the review period - a reasonable overhead. SSMI continues to have 5 international consultants and 9 national staff, recently replacing an international consultant with a national consultant when the opportunity was identified to deliver the same quality service at a reduced cost. Due to increased threats, security costs have increased, representing up to $25 \%$ of project costs." 33
\end{abstract}

\section{Merely meeting project goals is no guarantee of actual impact}

To date, the project has passed three annual DFID reviews (2012-2014) and a full mid-term review in mid-2013. Both DFID and Coffey International have adequate arrangements in

\footnotetext{
${ }^{33}$ DFID, SSMI Annual Report, 2014, http://devtracker.dfid.gov.uk/projects/GB-1-202109/documents/, August 2014
} 
place for regular monitoring and evaluation of the project. The project is also regularly monitored internally by the project team and externally by DFID. Finally, based on the information collected by MEC, DFID and Coffey International appear to be abiding by their own internal anti-corruption regulations and no substantiated allegations of corruption were received by MEC. Notwithstanding these reviews, MOI remains one of the most corrupt institutions in the country, with its total force strength an estimate-at best-and its capacity to prevent, detect, and deter sophisticated crimes and terrorist acts minimal. 


\section{Inaccurate Data Makes Assessments of the Afghan National Security Forces Challenging}

The U.S. government has allocated at least $\$ 3.6$ billion to pay the salaries of Afghan National Security Forces (ANSF) personnel since 2002. However, despite U.S. and coalition efforts to develop effective ANSF personnel and payroll processes, those processes continue to exhibit extensive weaknesses, incomplete or incorrect data, lack of integration between systems, and minimal oversight. As a result, there is limited assurance that ANSF personnel and payroll data is accurate.

As of December 2014, the U.S. government has provided $\$ 2.3$ to pay Afghan National Army (ANA) salaries and incentives since 2009. Since 2008, multiple U.S. oversight agencies have all identified numerous weaknesses in fundamental ANA personnel data, including limited U.S. and Afghan oversight of data collection processes, little or no physical verification of ANA personnel existence and daily attendance, and lack of controls over the ANA payroll process.

MoD's policies require it to collect ANA attendance data in daily and monthly status reports. Once ANA personnel and payroll data is collected, it is entered into a series of data systems using easily abused manual-entry and transfer processes. During visits to two corps headquarters, SIGAR identified no examples of direct oversight during attendance data collection and reporting. Instead, SIGAR found that the only monitoring mechanism in place to ensure accurate ANA attendance reporting was a sign-in sheet. Further, MOD continues to calculate ANA salaries manually, making the salaries vulnerable to manipulation and providing the U.S. government with little assurance that they are correct.

According to SIGAR, the U.S. military acknowledges in its own documents that once funding reaches the MOF, it "has very limited insights and oversight" as to what happens to the money. For example, the U.S. Department of Defense's Inspector General found that MOI processed 4,579 potentially improper salary payments totaling $\$ 40$ million due to the ministry's lack of procedures to identify misallocated payments. SIGAR also determined found that the ANSF continue to pay salaries for some ANA and ANP personnel in cash, using a ministry-appointed "trusted agent," and that this mechanism could allow corrupt actors to abscond with as much as half of an ANP officer's salary.

Sources: Multiple SIGAR audits and Quarterly Report to the U.S. Congress, www.sigar.mil, 2015.

\section{Norway: Prison Advisory Project}

Location: Faryab province

Date: $\quad$ 2007-2011

Cost: $\quad \$ 1.56$ million $^{34}$

Partner: $\quad$ ACTED

\footnotetext{
${ }^{34}$ Royal Norwegian Embassy (RNE), Kabul, response to information request from MEC, 2014. According to the RNE, the total cost of this project was NOK $11,746,479$. In 2015 U.S. dollars, this is approximately $\$ 1.56$ million. Note that no adjustments for inflation have been made in this report.
} 
The prison project in Maimana was initiated at the request of the Faryab PRT, the provincial prison department, and Norwegian advisors stationed in Kabul. The justification for the project cited the importance of improving the general conditions for the prisoners and strengthening Afghan prison officials' commitments to human rights, with a particular emphasis on female prisoners.

\section{Efforts to build capacity were highly localized and of dubious replicability}

The Ministry of Justice's Central Prison Department (CPD) was the Afghan government counterpart in this project. Its role concentrated on overseeing the quality of the construction work. The CPD did not play a significant role in problem identification, design, planning, or budgeting, although Norwegian-funded advisors did try to ensure a substantive role for provincial prison administrators in other areas. The passive role of the CPD-the countrywide prison administrator-deprived it of true ownership over this project and prevented it from obtaining essential capacities to disseminate lessons learned to other provincial prison departments. Creating a capable team of prison personnel (male and female) was one of the project's signal achievements, but it remains uncertain as to whether the CPD will be capable of maintaining the unit's cohesion and observing the principles and standards taught to them by the advisory team. While representatives from CPD occasionally visited the project in Maimana to monitor the activities, and helped the IP and the prison's administrators in resolving existing obstacles to project implementation, the inadequate participation of CPD remained a matter of concern throughout the life of the project. One result of this is that it remains an open question whether the limited financial resources of the Afghan government can support this prison over the long term.

Despite the fact that the newly created administrative systems were highly appreciated by prison officials, there is no evidence that the systems would be adopted beyond the provincial prison in Faryab. Long-term, sustainable prison reforms demand efforts to strengthen national structures that can play a role similar to that played by the advisors in disseminating international best practices nationwide. This can include assisting provincial prisons in accounting for income and expenses, including O\&M costs, and then entering into a dialogue with the CPD in Kabul regarding realistic budgeting and resource allocation.

\section{Leading local prison official questions value received for donor money expended}

The head of the provincial prison department reported to MEC that he is of opinion that the activities carried out by this project seem of less value than the money invested in it, making him doubtful that the funds were well spent. Updated independent financial and performance audits of this project would be required to ascertain the validity of this contention (although ACTED did have auditors in Faryab province, who reportedly verified financial documents submitted by contractors to mitigate any possible corruption during the project's life).

\section{Health}

EU: Provision of Basic Package of Health Services (BPHS) in Kunduz Province Location: Kunduz province

Dates: $\quad$ November 2011 - May 2013

Cost: $\quad \$ 5.60$ million (€4.84 million) 
Partner(s): Merlin

Due to a poorly functioning health care system, in 2003 the MOPH designed a BPHS and an Essential Package of Hospital Services (EPHS) that still serve as a crucial part of MOPH's overall strategy for delivering services to the Afghan population. The BPHS's main objectives are: (1) to provide a standardized package of basic services that are the core of service delivery in all primary care facilities; and (2) to promote the redistribution of health services by providing equitable access, especially in underserved areas. The needs assessment for the BPHS in Kunduz province was conducted by Merlin, while the MOPH's Grant Contract Management Unit (GCMU) was responsible for M\&E work. An MoU was also signed between the MOPH and Merlin, in which the roles and responsibilities of both parties were outlined. The BPHS in Kunduz is part of a nationwide program, but, here, MEC only addresses the BPHS as it was implemented in Kunduz province.

\section{An example of a valuable unit successfully established by international agency within an Afghan ministry}

The GCMU was established by World Bank in 2003 and serves as the government counterparty for this project. The GCMU was initially formed as a team of 2-3 advisors supported by donors. Today, the GCMU is a relatively large team, consisting of local medical specialists and staff in other fields, including financial management, procurement, M\&E, and logistics. They are responsible for monitoring and technical support to other NGOs and for the coordination of the project. Contracting tasks were also the responsibility of this team. The GCMU received intensive training and it is expected to serve as an asset for project sustainability since it is now part of the MOPH's organizational structure.

The joint effort to enhance mutual accountability and build greater Afghan ownership that were made under the auspices of this project by both the EU and the MOPH can be considered a best practice worthy of emulation where circumstances permit. However, given the poor employee incentive structure of GIRoA, the major challenge for the MOPH will be to keep the necessary personal as a part of the GCMU over the long term.

\section{Joint monitoring and evaluation efforts difficult to assess}

The project proposal included defined benchmarks and measureable results, alongside a set of indicators that were monitored regularly throughout the project's lifespan. The BPHS is among the limited number of off-budget projects in which the government counterparty, the GCMU, was pro-active in its monitoring and impact evaluation efforts. Monitoring and evaluation of the project was also conducted by analyzing the information collected during the visits undertaken by EU staff, as well as by external experts commissioned to conduct project monitoring and evaluation. Additionally, the EU facilitated visits by provincialgovernment and CSO representatives to supplement other monitoring efforts already in place. The project was audited internally by the EU and externally by an independent body, but these reports were not made available to MEC.

\section{Low-quality pharmaceuticals potentially slipped past monitors}

Despite the efforts made both by the EU and GCMU to mitigate possible corruption, MEC's review of this project exposed the significant risk that outdated, low-quality pharmaceuticals 
and medical equipment were sometimes used. A separate, technical investigation would be required to discern the breadth of such problems.

\section{Overhead costs}

In May 2015, an EU representative reported that, together, security, rent, and other administrative costs accounted for $8.4 \%$ of the contract's total value. As the objective of this contract was to provide medical services, the EU did not include salaries for doctors, nurses, and other medical professionals in this calculation (those accounted for more than $50 \%$ of the contract's costs). ${ }^{35}$

\section{Agriculture}

EU: Natural-resource Management Activities in the Upper Catchments of Kunduz Sub-river Basin

Location: Bamyan and Baghlan provinces

Dates: $\quad$ August $2011-$ April 2015

Cost: $\quad \$ 3.13$ million ( $€ 2.70$ million $)^{36}$

IPs: $\quad$ Primarily, Solidarities International Association (SI)

This project was designed to support Afghan water and pasture policies, following the 2009 Afghan Water Law and guidelines propounded by the Ministry of Agriculture, Irrigation and Livestock (MAIL); the Ministry of Energy and Water (MOEW); and the River Basin Agencies (RBAs). The project included creating Water User Associations (WUAs) and Catchment Management Associations (CMAs) in the targeted communities.

Four Ministries-the Ministry of Rural Rehabilitation and Development (MRRD), MOEW, MAIL, and the Ministry of Economy (MOE) - were the government counterparties for this project. Their role was primarily confined to monitoring activities and defining certain policies. The ministries played a limited role in other aspects of project administration, which could reduce the chances that the beneficial aspects of this program will be incorporated into the ministries' respective policies and procedures.

\section{Local institutions established, but their sustainability depends on local commitment}

One of the major achievements of this project was the establishment of WUAs and CMAs that were registered with the MOEW and MAIL. One WUA was established for each irrigation canal, which is the joint property of the households having water rights to this canal. The purpose of creating WUAs was to foster better irrigation management and disputeresolution processes. A number of CMAs were also established through this project in Bamyan and Baghlan provinces. The CMAs are registered with MAIL, and are responsible for resolving grazing conflicts.

Although the project was coordinated with the River Basin Agencies and River Sub-Basin Agencies, as well as with the WUA and other associations at provincial level, relevant

\footnotetext{
${ }^{35}$ EU Delegation to Kabul, Director of Finance, email to MEC, May 2015.

${ }^{36}$ For this contract, the EU reported that the budget included only two main headings: "fees and incidentals, so no overhead [was] reported as such," EU Delegation to Kabul, Director of Finance, email to MEC, May 2015.
} 
officials in provincial MAIL, MOEW, and MRRD offices are of the opinion that the project's activities were not adequately coordinated with them. Officials from these ministries who are based in Kabul concurred, stating that they had little knowledge of the project's details, though perhaps that is a natural consequence of this being a provincially focused project.

\section{Mixed reviews from local officials as to the project's effectiveness}

According to a MAIL official in Bamyan, the project achieved about $60 \%$ of its expected results (MEC received no evidence to substantiate this figure), mainly because the SI field engineers were allegedly unqualified and underpaid. However, the officials in provincial departments of MOEW and MRRD were of the opinion that the project was a success, particularly in terms of improving the environment and better managing scarce water resources.

\section{Donor-supported government monitoring efforts}

Provincial government officials in Bamyan and Baghlan stated that both the EU and SI generously supported government efforts to monitor the project, but the provincial departments lacked adequate resources, such as vehicles, to carry out such missions on a regular basis. SI also attempted to provide provincial council members and other elected officials an opportunity to examine the project first-hand, but the results of this initiative are unclear.

\section{Seemingly positive effect on local economy}

This project had both a direct and indirect impact on the local economy in the two target provinces. The project affected the economy of the target communities by increasing the availability of water for irrigation; enhancing local capacity in carrying out operations and maintenance; increasing agriculture productivity through provision of adequate water to existing agricultural land; draining non-agricultural lands; and providing job opportunities to local farmers through increased farming activities.

In addition, local suppliers and service providers were hired to supply required goods and to provide essential services. But these contracts merely provided a temporary infusion of funds to a few local companies. And while there is no direct, tangible evidence that the project was affected by corruption, MEC did receive some reports of occasional interference by MPs and PC members in the planning process and the deployment of project resources.

\section{Questions about GIRoA's commitment to support project achievements over the long term}

Although there was no defined sustainability plan integrated into the project's design, certain measures were taken that could ensure the long-term sustainability of project's accomplishments, which included the creation of WUAs and CMAs and preparation of community-based plans in line with the Afghan Water Law. However, the lack of essential Afghan government capacities to carry post-project O\&M activities, or to undertake independently similar projects in the future, places the project's sustainability in doubt. It is also still uncertain whether the Afghan government is committed to continuing the project after foreign assistance ends.

\section{EU: Provision of Technical Assistance to MAIL}




\begin{tabular}{ll}
\hline \hline Locations: & $\begin{array}{l}\text { Kabul, Herat, Mazar-e-Sharif, Balkh, Kunduz, Nangarhar, } \\
\text { and Kandahar provinces. }\end{array}$ \\
Dates: & November $2010-$ December 2015 \\
Cost: & $\$ 8.05$ million (€6.95 million) \\
IP: & Agriconsulting SPA
\end{tabular}

The overall aims of this project include horticulture development through institutional and legislative reforms at MAIL; the establishment of demonstration gardens, capacity building in the horticulture sector (public and private); and the establishment of a database for horticultural sector, fruit exhibitions, and other agricultural developments. The project has been implemented by the Perennial Horticulture Development Program (PHDP), which also oversees other EU-funded activities in the agricultural sector. Ultimately, the PHDP aims at strengthening the public and private horticulture sectors, which could have an extremely valuable impact on this crucial economic sector. ${ }^{38}$

\section{Limited involvement by MAIL officials in Kabul}

MAIL is the government counterpart for this project. The role of the MAIL's horticulture department both in Kabul and in the target provinces is limited to monitoring the project, which is not conducted regularly due to lack of essential resources. However, the project includes a capacity-building program for MAIL technical staff in the horticulture, as well as in the provincial departments. Further, MEC's findings indicate that representatives from MAIL's horticulture department have not been invited to at least some of these coordination meetings, which keeps them unaware of the project's progress.

\section{Pre-scheduled inspection visits undermine effective monitoring}

The EU also monitors the project externally through spot visits, but the efficacy of these is undercut by the fact they occur on a pre-scheduled basis. Information gathered by MEC indicates that the horticulture department of MAIL is monitoring the project as well, but no evidence was available on how frequently this monitoring was conducted.

\section{The use of metrics and real-time interventions allow for some problems to be corrected posthaste}

The project proposal included measureable results at all levels and appropriate indicators. Progress in achieving these results is monitored regularly throughout the project life cycle. The project is also subject to internal and external monitoring and evaluation. Moreover, the project is monitored internally by IP field teams and the information can be immediately transferred to PHDP managers to take corrective actions in instances where it is necessary.

\section{Reports indicate well-connected individuals attempted to hijack aspects of the project}

Attempts of interference by influential local power brokers were reported to MEC. The goal of these persons appears to be the diversion of project activities to their areas of interest or

\footnotetext{
${ }^{37}$ EU Delegation to Kabul, Director of Finance, email to MEC, May 2015.

${ }^{38}$ Agriculture is the major income source for around $80 \%$ of Afghans and horticulture products (primarily fruits) make up one of the country's major exports.
} 
control. While these reports remain unconfirmed, a comprehensive final project audit and an investigation of these allegations appears warranted.

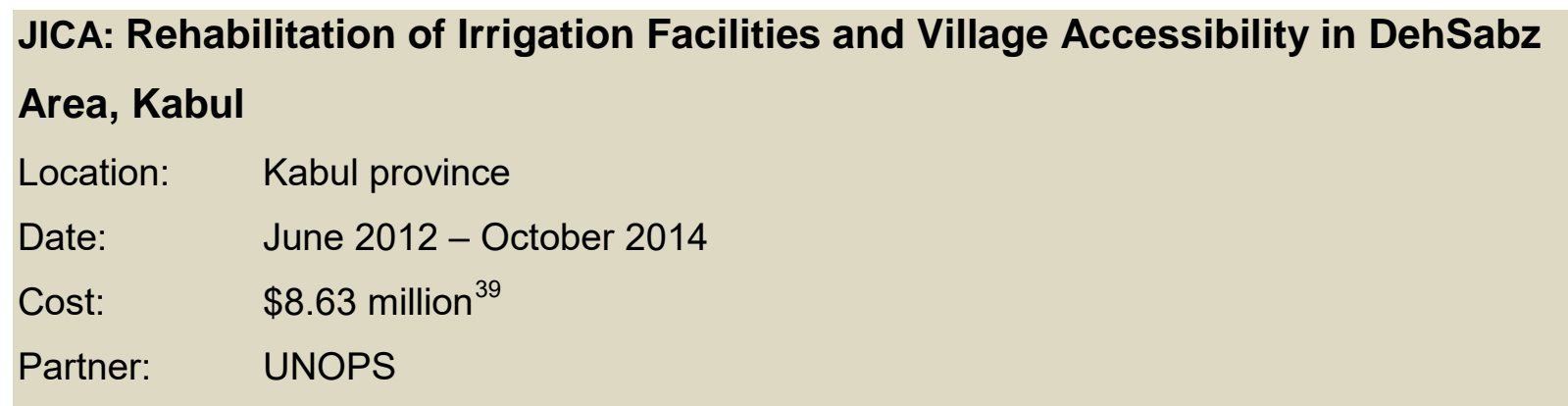

This project aimed at achieving improved irrigation systems and roads in collaboration with the Dehsabz-Barikab City Development Authority (DCDA). It was requested by DCDA, which collaborated with UNOPS during its implementation. The main responsibility of DCDA was monitoring, which it conducted jointly with JICA and UNOPS.

\section{Training of local government personnel}

DCDA officials received training in project design, project management, needs assessment, surveying, and M\&E work. UNOPS also attempted to build the capacity of DCDA staff by assisting them with preparing meeting reports and status updates, facilitating the participation of DCDA joint-inspection visits, monitoring the project's progress, resolving communityrelated obstacles, and preparing a major inspection report. DCDA, in collaboration with JICA and UNOPS, attempted to build the capacity of private construction companies, service providers, and suppliers in modern project management, observing safety standards, and using high quality materials. The equipment, supplies, and other project properties were to be given to DCDA, and UNOPS was to coordinate a formal handover ceremony for all properties, goods, and equipment at the end of the project.

\section{Monitoring and evaluation}

Joint site-inspection visits involving the DCDA, JICA, and UNOPS were also conducted on monthly basis. Comprehensive monitoring arrangements existed within UNOPS and JICA, and the project was monitored internally by UNOPS and externally by JICA on regular basis. Since the project's inception, UNOPS organized regular joint-inspection visits, sharing their reporting with DCDA and JICA.

Evidence gathered by MEC shows that the DCDA team was capable of undertaking all functions throughout the project's lifespan, which is a sign of relatively higher ownership over the project processes.

\section{Local impact}

According to DCDA's Director of Project Management, local residents are satisfied with the project's results. In particular, he cited the higher quality of the seeds provided to local farmers under the auspices of this initiative as contributing to overall improved harvests. Although unverified, he estimated that wheat production in some target areas had doubled when measured against yields from before the project's commencement. He also stated that

\footnotetext{
39 JICA, information provided in response to a MEC request (in U.S. dollars), 2014
} 
a secondary consequence of this project was that the community is now more closely linked to other facilities in Kabul, enabling residents to take greater advantage of government services.

\section{Sustainability plan}

The project has a one-year guarantee period, during which the contractor is obliged to carry any required maintenance or repairing work. To ensure that the contractor acts upon its obligations during guarantee period, UNOPS keeps a percentage of contracted cost unreleased (up to 10\%) until the end of the period and receipt of confirmation that all contractual obligations have been met.

\section{Infrastructure}

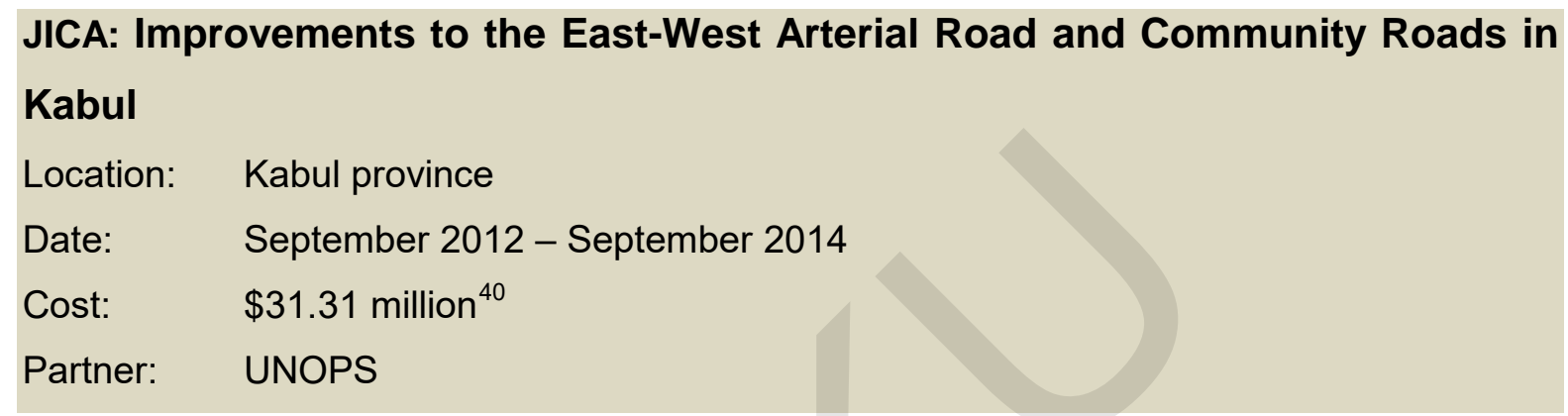

This successful project involved work on roads running near Kabul International Airport, as well as several other roads northwest of Kabul. Kabul Municipality collaborated with UNOPS to implement the project, and the concept was based on a prior study conducted by KM staff.

\section{Local Afghan officials took an active role in certain aspects of the project}

UNOPS utilized the capacity of $\mathrm{KM}$ and district-government personnel throughout the implementation of project by directly engaging with their leadership and engineering staff. KM staff took part in resolving technical and land-related issues; project inspection visits; and liaising with other government institutions, but played a limited role in the purely technical aspects of the project-administration process.

The MoU and Agent Agreement signed between the KM and UNOPS included the commitment of both parties to disclose their activities and share information throughout the life of the project. Beginning in March 2014, the project conducted regular joint-inspection visits with $\mathrm{KM}, \mathrm{JICA}$, and other key stakeholders, and inspection reports were shared with $\mathrm{KM}$ and JICA.

UNOPS trained KM staff and supplied the KM Maintenance Department with the roadmaintenance equipment identified by department personnel. However, it will require continued scrutiny to determine whether these efforts have enabled KM to sustain the improvements brought about by the project after the assistance phase terminates.

\section{Local officials satisfied}

\footnotetext{
${ }^{40} \mathrm{JICA}$, information provided in response to a MEC request (in U.S. dollars), 2014.
} 
In early 2015, MEC interviewed Kabul Municipality officials knowledgeable about this project. According to the Municipality's Deputy Director for Policy and Coordination, the improved roads have allowed for residents living in the vicinity to use safer, more direct routes into other areas of Kabul. To assess the economic effects of this improved access and measure it against the costs of the project, however, would require comprehensive audit work beyond the scope of MEC's capacities. That said, the Deputy Director and his associates seemed confident in the project's overall utility.

\section{A Nationwide Challenge: The Costs of Road Reconstruction}

A 2007 report authored by an Integrity Watch Afghanistan (IWA) official illustrates the challenges faced by donor-funded road projects. Essential to linking distant parts of the country together with its major economic hubs, such as Kabul, improving Afghanistan's primitive road network has been a reconstruction priority for more than a decade. As a former U.S. military commander stated, "Wherever the road ends, that's where the Taliban starts." According to the study, the average cost of a kilometer of road was between $\$ 123,000$ and $\$ 589,000$ (2007 dollars), with security concerns and rough terrain serving as the main factors driving up project costs. But some road projects have cost far more. As noted in the aforementioned IWA report, the cost of upgrading the Bibi Mahro in Kabul, where security was less of a concern and the terrain was relatively forgiving, came in at more than \$2.4 million per kilometer. The road was funded by USAID who used Louis Berger Group as the prime contractor, a company whose costs incurred for a variety of projects in Iraq and Afghanistan would later be called into question by U.S. oversight agencies.

Among the other major factors driving up the price of road projects are the relatively higher costs associated with importing materials from abroad, the need to pay local warlords protection money to ensure the safety of project staff, the use of multiple subcontractors (for example, USAID used UNOPS as an intermediary between itself and the prime contractor on some provincial-road projects, with the latter's overhead costs running between $10-15 \%$ of project costs), unrealistic deadlines, and the outsourcing of maintenance services to local companies. As early as November 2003, a USAID memorandum warned that prime contractors are not conducting sufficient oversight of their subcontractors, leading to delays, inefficiencies, and higher costs. The multiplicity of actors involved in many road projects makes oversight challenging, allowing for unscrupulous persons and groups to inflate contract costs for their own benefit.

Source: "Afghan Roads Reconstruction: Deconstruction of Lucrative Assistance," L. Delesgues, IWA, http://www.integrityaction.org/sites/www.integrityaction.org/files/documents

\section{JICA: Improvement of the Existing Bamyan Airport Project}

\section{Location: Bamyan province}

Date: $\quad$ November 2012 - November 2014

Cost: $\quad \$ 15.72$ million $^{41}$

IP: $\quad$ UNOPS

This project supported improving the existing Bamyan Airport. It included the construction of

\footnotetext{
${ }^{41} \mathrm{JICA}$, information provided in response to a MEC request (in U.S. dollars), 2014.
} 
a runway, a runway strip, terminal building, utility building, and a fire station. The project also provided the airport with essential equipment, such as fire trucks, tools, and navigation devices.

\section{Collaborative effort improves vital infrastructure}

The Ministry of Transportation and Civil Aviation (MOTCA) collaborated with UNOPS during the implementation of the project. According to Afghan officials, the need for the project was identified by the Ministry, with survey and soil testing carried out by the New Zealand PRT in Bamyan. The project aligned with Afghanistan's NPPs, and UNOPS utilized the capability of the Ministry and its district personnel to resolve technical and land-related issues and coordinate with government institutions and powerful individuals in the area.

Using the opportunities within the project, UNOPS also attempted to build the capacity of MOTCA staff in some secondary areas, including the preparation of meeting agendas and the resolution of community-related obstacles. In addition, UNOPS directly engaged with existing MOTCA departments and trained their personnel throughout the implementation phase of the project. UNOPS supported MOTCA and Bamyan Airport officials in the purchasing of technical equipment and provided procurement training to MOTCA staff. A technical team (including air-control personnel) was established and trained in Bamyan to execute O\&M activities at the airport after the project's conclusion.

Except for the essential navigation and weather equipment and tools, which are not available in local markets, all other required goods and materials were procured locally, introducing the usual mix of benefits (increased economic activity) and problems (potentially unreliable contractors with links to corrupt actors). Most importantly, however, this JICA-funded project made a significant contribution to making one of Afghanistan's most historically significant provinces more accessible. While no comprehensive studies have been to assess the quantitative economic impact of the airport improvements; qualitatively, interviewees repeatedly informed MEC that the project has had a positive effect on the province, strengthening its connections to the rest of Afghanistan.

\section{All parties endeavored to implement adequate M\&E and anti-corruption plans}

Both JICA and UNOPS had adequate monitoring and evaluation arrangements. The project was monitored internally by UNOPS and externally by JICA. Since the project's inception, annual joint-inspection visits were organized by UNOPS, in which JICA, the Afghan government, and other stakeholders participated.

UNOPS applied its own rules and regulations for procurement of goods and services, as well as for staff recruitment, which potentially mitigated corruption to some extent. And while MEC received scattered reports that attempts were made by powerful officials to influence the project for their personal benefit-mainly by obtaining contracts-their efforts appear to have been detected and prevented by the joint efforts of UNOPS and the provincial MOTCA.

\section{Sustainability}

According to UNOPS, it introduced high-level professional standards to MOTCA, and provided the Ministry's relevant departments with professional benchmarks, which could be applied to future projects. Besides the infrastructure work carried out, the project also 
created two teams of professionals-a technical team responsible for maintenance and an airport-administration team.

As is the case with other JICA projects, the project has a one-year guarantee period, during which the contractor is obliged to carry any required maintenance or repairing work. But while JICA provided the Ministry with equipment and machinery for technical maintenance, it is unclear who will fund the O\&M costs over the medium-to-long-term.

\title{
8. Humanitarian Assistance
}

\author{
Norway: Humanitarian Response \\ Location: Nangarhar, Kabul, Faryab, Sar-e-Pul, and Herat provinces \\ Date: 2008 \\ Cost: $\quad \$ 1.06$ million $^{42}$ \\ IP: $\quad$ Norwegian Refugee Council (NRC)
}

This project was undertaken based on needs assessment conducted by UN agencies in collaboration with the Afghan National Disaster Management Authority (ANDMA), which was also engaged in the site-selection process. It assisted refugees, returnees, and internally displaced persons (IDPs) by providing them with emergency educational assistance; school supplies; and access to land, services, and shelter materials.

\section{Limited use of indigenous capacities}

ANDMA was the lead GIRoA entity in this project, with MORR and MOE playing subordinate roles. However, none of these institutions appear to have had significant involvement in many key areas, including project design, planning, budgeting, and monitoring and evaluation. Existing documents indicate the leading role of the NRC throughout the project's lifecycle. NRC carried out all procurement, recruitment, and IP- and contractor-selection tasks. ANDMA, although it possesses relatively highly trained teams, was not widely utilized in this project, which could have affected the quality of project implementation, as well as its cost effectiveness.

\section{Expedient measures, justified by exigent circumstances, precluded real mutual accountability}

No evidence was available about how the NRC and ANDMA were accountable to each other and to the people for project's results. But, as is noted in much of the literature on the Paris Declaration on Aid Effectiveness, it is often difficult to adhere to the principle of mutual accountability in humanitarian-response projects because the overriding priority is to expedite the delivery of goods and services to the affected populations.

Given the large scale of the displacement, there was a dire need for immediate assistance to these vulnerable groups. Understandably, the emphasis was on creating rapid assessment and response teams. Thus, strengthening the capacities of relevant government institutions and creating response mechanisms to provide humanitarian response more efficiently over

\footnotetext{
${ }^{42}$ In 2014, the RNE reported that the project cost "NOK 8,000 (x 1,000)," which is approximately $\$ 1.06$ million in 2015 U.S. dollars.
} 
the long term constituted second-tier priorities, and were difficult to achieve due to myriad factors, many of which were beyond the control of the parties.

\section{Allegations of corruption raise questions about aspects of the beneficiary selection process}

MEC received a number of unconfirmed complaints from residents in Herat and Nangarhar provinces about illegal interference by local officials in preparing the lists of beneficiary households for assistance. MEC also received similar reports about the involvement of such parties in the procurement of essential shelter materials and school supplies. These complaints raise concerns about the proper use of project funds. A beneficiary-satisfaction survey, accompanied by a deeper investigation of the beneficiary lists, and an assessment of the quality and quantity of shelter materials provided would help to address these allegations.

\section{Malnutrition Remains a Dire Problem for Afghan Children}

According to the UN-supported National Nutrition Survey, approximately 500,000 Afghan children under the age of six will require treatment for malnutrition in 2015 . Recently, UNICEF's chief official in Afghanistan was quoted as saying that "close to 15\%" of those 500,000 may not survive. The Survey further notes that up to $40.9 \%$ of Afghan children under six suffer from "stunted" growth due to poor nutrition. The World Bank estimates that malnutrition, and its associated consequences, costs the country at least $2-3 \%$ of its annual GDP growth each year. The problem is particularly severe in Helmand province and amongst IDP communities, as well as in the more remote parts of the country where basic services are limited. Among the major causes of childhood malnutrition cited by NGOs working in the field are poor security-making it difficult for food aid to reach affected populations-the lack of knowledge among Afghan mothers about proper childhood dietary requirements, and surging opium production in some of the country's most fertile areas.

Agriculture has generally been a much lower priority than security assistance. According to a 2009 study, USAID agricultural assistance amounted to only $1 / 30^{\text {th }}$ of U.S. funds spent on non-security programs. From Fiscal Year (FY) 2010 to FY 2014, USAID's Food of Peace initiative contributed more than $\$ 405$ million in food aid throughout Afghanistan. While substantial, this number pales in comparison to the $\$ 4.1$ billion that the U.S. Congress appropriated to assist the Afghan National Security Forces just in FY 2015. Although superficial, this comparison illustrates the funding discrepancies that have been in evidence since the fall of the Taliban. The two factors-food security and traditional military securityare undoubtedly intertwined, but the fact remains that, after more than 14 years of the largest international reconstruction program in history, many of Afghanistan's children have yet to benefit from the deluge of foreign assistance that has poured into their country.

Sources: "The Starving Children of Helmand Province, Foreign Policy, http://foreignpolicy.com/2015/05/01/the-starving-childrenof-helmand-provincel, May 2015 and "Afghanistan: Food Insecurity the Problem that Never Went Away,"http://www.eurasianet.org/departments/insightb/articles/eav021009b.shtml, Eurasianet, February 2009; SIGAR Quarterly Report to the U.S. Congress, www.sigar.mil, April 2015.

Norway: Shelter and ICLA Response to Returnees and IDPs.

Location: Eastern and northern Afghanistan (and Pakistan)

Date: $\quad 2008$ 
Cost: $\quad \$ 4.35$ million $^{43}$

IP: $\quad$ NRC

This project included several components: the construction of 1,000 family dwellings; resolving 124 land disputes in northern Afghanistan; registering 100 property cases; resolving 100 other administrative cases; and delivering basic knowledge about sustainable shelter construction to 1,000 community representatives.

\section{MEC found that incomplete information was sometimes provided to the central government}

This project was implemented in collaboration with the MORR and its district representatives. The role of the government was more obvious at provincial and district levels, but based on information received by MEC, the relevant MORR departments in Kabul had very little information about the project. Interviewees informed MEC that information about the project was not adequately communicated with senior MORR personnel. According to these officials, they were not engaged in the design, management, or evaluation of the project. Further, high-ranking MORR officials themselves expressed to MEC great concern over the low human and institutional capacities in their departments, which further isolated them from the project.

\section{Procurement practices appear to have been transparent}

In beneficiary selection, the NRC applied standard UNHCR guidelines, while all procurement and recruitment tasks were carried out in accordance with NRC procedures. The shelter design was reported to have been done in accordance with recognized international standards and UNHCR - Afghanistan shelter guidelines. Local contractors were used for service delivery and the supply of essential goods and materials identified in close collaboration with provincial representatives from MORR and MOJ, using NRC rules and guidelines. $^{44}$

\section{Custom-tailored monitoring techniques yielded uneven results}

NRC reported that they adopted unique arrangements for monitoring and evaluating some projects, such as debate sessions organized with stakeholders, including the government, CSOs, and other stakeholders to assess project implementation. This degree of community involvement could be used effectively in other projects to provide near-real-time feedback from beneficiaries and other affected parties. NRC also used volunteers in target communities to obtain information about the problems associated with the project. In addition, NRC disseminated mobile numbers to elders in target communities to contact in case of any project-related problem. Notwithstanding these innovations, serious concern existed in MORR about the lack of formal M\&E mechanisms, which precluded MORR personnel from regularly visiting the project sites.

\section{Ephemeral economic effects}

All procurement was reportedly carried out in accordance with NRC guidelines and procedures. Before the start of the construction, local masons were identified and trained on

\footnotetext{
${ }^{43}$ In 2014, the RNE reported the project cost "NOK 32,786 (x 1000)," which is approximately $\$ 4.35$ million in 2015 U.S. dollars.

${ }^{44}$ Much of this information is impossible to verify, given the transitory nature of the project and its remoteness in time.
} 
UNHCR shelter and latrine standards. More than 60 local masons were involved, along with NRC technical and monitoring teams. Where possible, NRC procured all required goods, services, and equipment, including rental vehicles, in the local market from local suppliers. But when the project ended, so, too, did most of these contracts. As a result, the economic impact, if any, was scant.

\section{Allegations of corruption plagued the beneficiary-selection process}

NRC anti-corruption measures in this project included enhancing the awareness of its staff about corruption, applying sanctions against those committing corruption, and strengthening monitoring and oversight procedures. But the procurement of shelter materials, recruitment of field staff, development of beneficiary lists, and hiring of local contractors were vulnerable to corruption. According to one MORR official interviewed by MEC, the lists of shelter beneficiaries allegedly included a number of people who had paid bribes to be included, even though they were not entitled to shelter support. These allegations were not confirmed by other MoRR officials or by NRC representatives when they were interviewed by MEC.

\section{Suggested Policy Reforms}

To address the existing weaknesses and challenges in the implementation of foreign assistance programs, MEC urges donors and the Afghan government, in accordance to their commitments under the Paris Declaration on Aid Effectiveness, to support and implement the recommendations set forth below.

\section{Accountability and Transparency}

A joint, multilateral, and independent commission for aid effectiveness should be established to monitor foreign-aid practices, identify deficiencies, and make recommendations. Furthermore, donors and the Afghan government should collectively agree on indicators of aid effectiveness. The commission may also wish to consider issuing an annual "report card" for each donor, highlighting their respective levels of achievement. The establishment of such a body could also provide civil-society organizations with greater access to information about assistance programs, concomitantly increasing their ability to monitor them.

One recent example of effective oversight on the national level was USAID's halting of contract awards to International Relief and Development (IRD), its largest nonprofit contractor active in Iraq and Afghanistan, because an internal investigation found IRD to have allegedly engaged in "serious misconduct." 45 These developments, which occurred in late January 2015, are an example of the sort of oversight that all parties involved in the funding, delivery, and management of foreign assistance to Afghanistan should be engaged in on a regular basis.

On the other hand, the recent-albeit short-lived-decision by the U.S. Department of Defense to classify many details about U.S.-funded support to the ANSF (after years of disclosing such information to the public) exemplifies precisely the type of tactic that prevents

\footnotetext{
${ }^{45}$ IRD received more than \$1 billion in contracts for work in Afghanistan between 2006 and 2014.
} 
the donor nation's citizens and government from obtaining the information necessary to assess the nature and the quality of the assistance provided to them. ${ }^{46}$

\section{Uniform Definition of Overhead Expenses and Indirect Costs}

To provide all stakeholders with a transparent picture of the operations of a foreignassistance program, donor organizations should agree to employ common terminology when referring to contract costs not directly spent on deliverables. Reaching agreement on this issue would be challenging-and, in some cases, impractical. That said, donors should make every effort to abide by mutually agreed terms and categories for such expenditures as salaries, rent, security, administrative costs, vehicles, supplies, paid vacations, and so forth. This would enhance transparency and accountability and provide the Afghan government with a clearer picture of how much money is actually being spent to help the Afghan people.

\section{Allocation of Assistance}

Donors should strive to base their assistance on multi-year aid commitments, assisting the Afghan government in developing the long-range planning capacity it will need in the future. A key component of such planning is incorporating realistic, detailed funding plans for operations and maintenance costs for development projects. Here, the SPAD program constitutes a step in the right direction. But to avoid aid dependency, the Afghan government must concomitantly strengthen its efforts to increase domestic revenue collection by reducing corruption, enhancing border security, and growing the tax base.

\section{Compiling Afghan-Specific Best Practices for Future Use}

The international donor community, in collaboration with the relevant ministries in Kabul, should consider forming a joint body whose purpose would be to collect and disseminate foreign-assistance best practices in format accessible to future practitioners. For too long, staff turnover among Embassy personnel has led to the loss of institutional memory and the repetition of avoidable mistakes that had been made before in similar contexts. A combined effort on the part of all major stakeholders could serve as a valuable resource to teams implementing projects in the years to come.

\section{Contractors}

Donors should only use contractors who have a record of efficiency, and avoid multiple layers of sub-contracting. Donors should also attempt to agree to common rules for contracting and tendering, and have arrangements in place for IP and contractor assessments.

\section{Coordination and Alignment}

Donors should use existing mechanisms to improve donor-government coordination. Donors should also provide the government with timely, comprehensive, and accurate information on aid flows, and ensure they are consistent with national and local development priorities. To accomplish this, the DAD should be overhauled and simplified to allow all stakeholders complete access to aid information in a cognizable and timely manner.

\footnotetext{
${ }^{46}$ In early 2015, the Commanding General of U.S. Forces - Afghanistan backed away from the initial classification decision, and much of the information was subsequently made available to the public.
} 


\section{Decentralization}

The central government should give serious consideration to decentralizing those government functions that could be conducted more effectively by provincial and district bodies. There should also be greater participation by provincial institutions in the national budget process, and in the formation of national development plans, in order to integrate provincial plans into the national budget.

\section{Distribution of Aid}

There is a need to conduct a comprehensive and objective assessment of the reconstruction, development, and humanitarian needs of Afghanistan's provinces, and, correspondingly, reconfigure government, donor, military, and NGO spending to target the neediest regions. This would help to ensure a more equitable distribution of resources and a higher level of support for areas with greater development and humanitarian needs. As partially demonstrated by the example of CERP, funds spent in insecure provinces often yield little in the way of tangible dividends.

\section{Enhanced Partnerships}

Donors should increase the proportion of joint analytical and M\&E work performed during the implementation phase of most projects. This would not only present increased opportunities to build Afghan capacities, but it would also provide the donor community with a more realistic appraisal of these institutions-and of the effectiveness of their assistance programs.

\section{Ownership and Governance}

To maximize Afghan ownership of the development process, donors should seek to increase the volume of funds channeled through the core budget, especially the development component of the budget. To justify this, the Afghan government must continue to take steps to improve its budget-execution capacities; strengthen its financial management and fiscal controls; expedite public-administration reforms; ensure implementation of a robust anticorruption strategy; reform sub-national governance; decentralize ministerial operations; and expand the participation of communities and civil society in designing, implementing, and monitoring development activities. Here, a true partnership is necessary. As the Afghan government improves its ability to manage funds, donor countries could prove more willing to entrust them with additional resources.

\section{Quality of Aid}

Donor emphasis should remain tightly focused on ensuring that programs are demanddriven, address needs identified by Afghans, build local capacities, and are accountable to Afghan institutions. Increased aid should be directed toward projects that benefit people living in rural areas, and gender-equality objectives should remain a primary consideration in the design and implementation of relevant development activities. Each donor should also institute an annual aid review to measure its overall performance (if it does not already do so), releasing it to the public upon its completion. Ideally, these reviews would be executed with significant input from the Afghan government, especially regarding what criteria are employed to measure the effectiveness of a project. 


\section{Technical Assistance}

Donors should ensure that technical assistance is cost effective, demand driven, coordinated, aligned with national priorities, and focused on building the capacity of national staff. Technical assistance should be continuous, strictly monitored, and followed by an annual capacity assessment to identify gaps and followed up with appropriate refresher sessions. 


\section{Conclusion}

Few would dispute that international-assistance programs have contributed to tangible improvements in some aspects of the life of the average Afghan citizen and the operational capacities of their government over the past 13 years. But the era of seemingly unlimited funds from abroad is drawing to a close. Cognizant of this reality-and the deleterious effects it is already having on the Afghan budget-President Ashraf Ghani is emphasizing the need for a greater degree of Afghan control over the development agenda. If properly executed, this would help to ensure that his and future administrations possess the institutional and technical capacities necessary to implement development programs with less reliance on the vicissitudes of donor budgets and ever-shifting international priorities.

MEC's review of the projects summarized in this report, while limited in scope, found that the relationship between the donor community and the Afghan government is still evolving, with donors becoming ever-more aware of the desirability to employ Afghan capacities, where possible, but still hesitant to do so because of the widespread corruption that affects many government agencies. In the near term, striking the proper balance between increased Afghan control and donor-managed oversight mechanisms that safeguard their taxpayers' funds will be one of the major challenges for the government and for the international community.

On the positive side of the ledger, many of the programs addressed in this report emphasized the need for continuous monitoring and evaluation of projects and the desirability of aligning development agendas with the priorities articulated by the Afghan government. Less positively, some programs downplayed the need for crafting detailed sustainability plans and ensuring Afghan buy-in for post-project operations and maintenance. The failure to plan for such activities calls into question the lasting effects of several of the projects covered herein, and raises broader questions about whether too many donors were driven by the short-term need to produce results, while paying an insufficient amount of attention to preparing the Afghan government to shoulder the burden of maintaining these projects once donor support comes to an end.

As stated at the outset, the goal of this report is to provide donors, the public, and the government with additional insight into the efficacy of the massive international-assistance program undertaken since the fall of the Taliban regime. The literature on this topic is vast, rich, and diverse, and it is our sincere hope that we have been able to make a contribution to it that will be valued both now and in the future.

\section{Acknowledgements}

MEC's governing Committee and its Secretariat would like to express their collective gratitude to everyone who contributed to this report. Most especially, we are grateful to the representatives of the donor community with whom we worked during the drafting process. Without the information they provided, this report could not have been written. 


\section{Annex I: Acronyms}

AA: $\quad$ Agent Agreement

AAA: Annual Audited Accounts

AC: Anti-Corruption

ACBAR: Agency Coordination Body for Afghan

Rehabilitation

AIF: $\quad$ Afghanistan Infrastructure Fund

AIRD: Afghan Institute for Rural Development

AITF: Afghanistan Infrastructure Trust Fund

ANDS: Afghanistan National Development Strategy

AGO: Attorney General's Office

AECC: Alaska Engineering and Road Construction Company

ANDMA: Afghan National Disaster Management Authority

ANP: Afghan National Police

AREU: Afghanistan Research and Evaluation Unit

ASI: Adam Smith International

ANA: Afghan National Army

ASCC: Afghan Sadaqat Construction Company

ASFF: Afghanistan Security Forces Fund

AUAF: American University of Afghanistan

ARTF: Afghanistan Reconstruction Trust Fund

AFMIS: Afghanistan Financial Management

AKF: Agha Khan Foundation

BPHS: Basic Package of Health Services

BSC: Beneficiary Selection Committee

CBO: Community- Based Organization

CDC: Community Development Council

CERP: Commander's Emergency Response

Program
CIDA: Canadian International Development

Agency

CMA: Catchment Management Association

CPD: Central Prison Directorate

CRP: Crisis Response Pool

CSO: Civil Society Organization

DAD: Development Assistance Database

DDA: District Development Assembly

DOD: U.S. Department Of Defense

DFID: Department for International Development

DCD: Development Cooperation Dialogue

DCl: Development Cooperation Instrument

DCDA: Dehsabz-Barikab City Development

Authority

DDA: Due Diligence Assessment

DoRR: Directorate of Refugees and Repatriation

EFSA: Emergency Food Security Assessment

EC: $\quad$ European Commission

EPHS: Essential Package of Health Services

ESF: Economic Support Fund

EU: $\quad$ European Union

FMIS: Financial Management Information System

GDP: Gross Domestic Product

GIRoA: Government of Islamic Republic of

Afghanistan

GLT: Growth and Livelihood Team

GCMU: Grant Contract Management Unit

HOO: High Office of Oversight and AntiCorruption

HQ: Head Quarters

IP: Implementing Partner 


ICT: Information and Communications
Technology
IDLG: Independent Directorate for Local
Governance
ICTAWG: International Community Transparency
and Accountability Working Group
IEC: Independent Elections Commission
INCLE: International Narcotics Control and Law
Enforcement

ITA: International Technical Assistance

IDP: Internally Displaced People

IARCSC: Independent Administrative Reform and Civil Service Commission

ICLA: Information Counseling and Legal Assistance

JCMB: Joint Coordination \& Management Board

JICA: Japan International Cooperation Agency

KCl: Kabul City Initiative

KM: Kabul Municipality

LOTFA: Law and Order Trust Fund for Afghanistan

MEC: Independent Joint Anti-Corruption

Monitoring and Evaluation Committee

MoU: Memorandum of Understanding

MDG: Millennium Development Goals

M\&E: Monitoring and Evaluation

MoJ: Ministry of Justice

MoF: $\quad$ Ministry of Finance

MoEC: Ministry of Economy

MoFA: Ministry of Foreign Affairs

Mol: $\quad$ Ministry of Interior

MoMP: Ministry of Mines and Petroleum

MDTF: Multi-Donor Trust Fund

MoPH: Ministry of Public Health

MoCl: Ministry of Commerce \& Industry
MoEW: Ministry of Energy \& Water

MAIL: Ministry of Agriculture, Irrigation and Livestock

MUA: Water Users Association

MSA: Management Service Agreement

MoTCA: Ministry of Transport and Civil Aviation

MoLSAMD: Ministry of Labor, Social Affairs,

Martyred and Disabled

MoRR: Ministry of Refugees and Repatriations

NDI: National Democratic Institute

NGO: Non-Government Organization

NRVA: National Risk and Vulnerability Assessment

NADF: National Agriculture Development

Framework

NOK: Norwegian Kroner

NFI: Non-Food Item

NAC: Norwegian Afghan Committee

NCA: Norwegian Church Aid

NPP: National Priority Program

NRC: Norwegian Refugee Council

NUC: New United Company

ODA: Official Development Assistance

PFEM: Public Finance and Expenditure Management

PIU: Project Implementation Unit

PIRC: Public Information and Research Center

PIN: $\quad$ People in Need

PRT: Provincial Reconstruction Team

PC: Provincial Council

P-ARBP: Panj-Amu River Basin Program

PHDP: Planting and Horticulture Development

Program 
PWG: Prison Working Group

PDC: Provincial Development Council

PD: $\quad$ Presidential Decree

RLS-I: Rule of Law Stabilization - Informal

\section{Component}

RIAP: Revenue Improvement Action Plan

RBA: River Basin Agency

RNE: Royal Norwegian Embassy

SOP: Standard Operation Procedures

SSMI: Strategic Support to Ministry of Interior

SPAD: Strengthening Provincial Administration and Delivery

SIGAR: Special Inspector General for Afghanistan

Rehabilitation

ToR: $\quad$ Term of Reference

TDR: Traditional Dispute Resolution
TFBSO: Task Force for Business and Stability

Operations in Afghanistan

TMAF: Tokyo Mutual Accountability Framework

TAF: The Asia Foundation

TA : Technical Assistance

USAID: United States Agency for International

Development

UNAMA: United Nation Assistance Mission for

Afghanistan

USA: United States of America

USFOR-A: United States Forces in Afghanistan

USACE: US Army Corps of Engineers

UK: $\quad$ United Kingdom

VfM: Value for Money

VCA : Vulnerability to Corruption Assessment 


\begin{tabular}{|c|c|c|c|c|c|}
\hline \multicolumn{6}{|c|}{ Aid Effectiveness } \\
\hline & Indicator & & Recommendation & Baseline & Status \\
\hline 1 & $\begin{array}{l}\text { Increased efforts by the international } \\
\text { community to transfer responsibilities for } \\
\text { development programs to the Afghan } \\
\text { government. }\end{array}$ & 1.1 & $\begin{array}{l}\text { IARCSC \& MoF intensify their efforts to } \\
\text { accelerate pay-grade reforms and ensure that } \\
\text { the advisory panel on senior appointments and } \\
\text { the Independent Administrative Reform and Civil } \\
\text { Service Commission (IARCSC) are effective, } \\
\text { fair, and transparent. }\end{array}$ & $\begin{array}{l}\text { (30. Dec. 2014) } \\
\text { Multiple sources report that the panel on senior } \\
\text { appointments and the IARCSC are not } \\
\text { adequately fulfilling their responsibilities to } \\
\text { employ fair, transparent, and merit-based } \\
\text { processes. }\end{array}$ & \\
\hline \multirow[t]{2}{*}{2} & \multirow{2}{*}{$\begin{array}{l}\text { Aid programs continue produce tangible } \\
\text { results after foreign financial assistance } \\
\text { ends }\end{array}$} & 2.1 & $\begin{array}{l}\text { Major donors consider a sustainability plan for } \\
\text { post-project operations and maintenance (O\&M) } \\
\text { in the program-design stage for their projects. }\end{array}$ & $\begin{array}{l}\text { (30. Dec. } 2014) \\
\text { Comprehensive sustainability plans for post- } \\
\text { project O\&M activities are not always included in } \\
\text { the project-design phase. }\end{array}$ & \\
\hline & & 2.2 & $\begin{array}{l}\text { MOF \& MOEC take concrete steps to decrease } \\
\text { the over-reliance on external funding to support } \\
\text { national development. }\end{array}$ & $\begin{array}{l}\text { (30. Dec. 2014) } \\
\text { Despite the overall reduction in funds for } \\
\text { development, the majority of sectors still remain } \\
\text { over-reliant on external funding. }\end{array}$ & \\
\hline 3 & $\begin{array}{l}\text { Afghan-specific donor best practices } \\
\text { captured in an accessible format for } \\
\text { future use. }\end{array}$ & 3.1 & $\begin{array}{l}\text { Major donors compile a compendium of "best } \\
\text { practices" to share with successor personnel at } \\
\text { their own agency and with their international } \\
\text { counterparts. }\end{array}$ & \begin{tabular}{|l|} 
(30. Dec. 2014) \\
Hard-won lessons and experiences are often not \\
captured in an accessible form for posterity \\
because of frequent staff turDecer at many donor \\
agencies.
\end{tabular} & \\
\hline 4 & $\begin{array}{l}\text { Measures taken to ensure that aid } \\
\text { programs are consistent with national } \\
\text { and local development priorities. }\end{array}$ & 4.1 & $\begin{array}{l}\text { Relevant ministries implement improved } \\
\text { processes to assuage donors' doubts about their } \\
\text { program management and budgeting procedures }\end{array}$ & $\begin{array}{l}\text { (30. Dec. } 2014) \\
\text { Alignment of aid programs with Afghan priorities } \\
\text { still a challenge although progress made in this } \\
\text { regard }\end{array}$ & \\
\hline \multirow[t]{2}{*}{5} & \multirow[t]{2}{*}{$\begin{array}{l}\text { Measures put in place to better } \\
\text { safeguard international-assistance funds } \\
\text { from corrupt actors. }\end{array}$} & 5.1 & $\begin{array}{l}\text { Key donors increase publicly available } \\
\text { information about their aid programs (e.g. } \\
\text { information on the long-term commitment of the } \\
\text { program, content, results, beneficiaries and } \\
\text { evaluation reports of the programs) at the } \\
\text { national and provincial level, by making it } \\
\text { available in the DAD. }\end{array}$ & $\begin{array}{l}\text { (30. Dec. 2014) } \\
\text { A significant amount of information on aid } \\
\text { programs would be difficult to access for rural } \\
\text { citizens or those lacking appropriate language } \\
\text { skills and/or internet access. }\end{array}$ & \\
\hline & & 5.2 & $\begin{array}{l}\text { Key donors harmonize their aid support with any } \\
\text { new anti-corruption strategy implemented by the } \\
\text { new government. }\end{array}$ & $\begin{array}{l}\text { (30. Dec. 2014) } \\
\text { The new government has not developed a new } \\
\text { national anti-corruption strategy. }\end{array}$ & \\
\hline \multirow[b]{2}{*}{6} & \multirow[b]{2}{*}{$\begin{array}{l}\text { Strengthened support for national } \\
\text { development policies and development } \\
\text { sccictsnns }\end{array}$} & 6.1 & $\begin{array}{l}\text { The Afghan government( MoF \& MoEC) } \\
\text { develops MoUs with all major donors in which } \\
\text { mutual obligations and responsibilities are clearly } \\
\text { identified. }\end{array}$ & $\begin{array}{l}\text { (30. Dec. 2014) } \\
\text { Not all the MoUs signed between donors and } \\
\text { GIRoA contain clearly defined mutual } \\
\text { commitments. }\end{array}$ & \\
\hline & & 6.2 & $\begin{array}{l}\text { The MoF and donors agree on a country-level } \\
\text { mechanism for mutual assessment of aid } \\
\text { effectiveness. }\end{array}$ & $\begin{array}{l}\text { (30. Dec. 2014) } \\
\text { No mechanism exists for a mutual assessment of } \\
\text { aid effectiveness. }\end{array}$ & \\
\hline
\end{tabular}




\begin{tabular}{|c|c|c|c|c|c|}
\hline \multicolumn{6}{|c|}{ Aid Effectiveness } \\
\hline \multicolumn{2}{|r|}{ Indicator } & \multicolumn{2}{|r|}{ Recommendation } & Baseline & \multirow[t]{2}{*}{ Status } \\
\hline & avosotalue & 6.3 & $\begin{array}{l}\text { Key donors ensure that all aid programs' impacts } \\
\text { are evaluated and financial expenditures are } \\
\text { independently audited and made available to the } \\
\text { public (contingent on donor countries' applicable } \\
\text { laws). }\end{array}$ & $\begin{array}{l}\text { (30. Dec. 2014) } \\
\text { Not every program is evaluated and audited } \\
\text { independently, and many such reports are not } \\
\text { made public. }\end{array}$ & \\
\hline \multirow[t]{2}{*}{7} & \multirow{2}{*}{$\begin{array}{l}\text { The information exchanged between the } \\
\text { Afghan government and donors is } \\
\text { improved in terms of quality, quantity, } \\
\text { and timeliness. }\end{array}$} & 7.1 & $\begin{array}{l}\text { The MoF drafts plans to improve the quality and } \\
\text { amount of information entered in DAD (e.g. } \\
\text { information on the long-term commitment of the } \\
\text { program, content, results, beneficiaries and } \\
\text { evaluation reports of the programs). }\end{array}$ & $\begin{array}{l}\text { (30. Dec. 2014) } \\
\text { The current DAD often lacks information about } \\
\text { multi-year donor commitments, aid programs' } \\
\text { contents and current funding status, and } \\
\text { program outputs. }\end{array}$ & \\
\hline & & 7.2 & $\begin{array}{l}\text { A restructured DAD is debuted by January } 2016 \text {, } \\
\text { in English, Dari and Pashto, and made } \\
\text { accessible to the public at large and to the donor } \\
\text { community. }\end{array}$ & $\begin{array}{l}\text { (30. Dec. 2014) } \\
\text { As currently constituted, it can be difficult to } \\
\text { obtain an accurate, complete, and up-to-date } \\
\text { picture of all aid programs from the DAD. }\end{array}$ & \\
\hline 8 & \begin{tabular}{|l|} 
A nationwide assessment of foreign \\
assistance is jointly conducted by GIRoA \\
and donor representatives to determine \\
sectors and regions most in need of \\
assistance.
\end{tabular} & 8.1 & $\begin{array}{l}\text { The MoF \& MoEC, in consultation with UNAMA, } \\
\text { drafts a plan to conduct an assessment that } \\
\text { takes into account the distribution of funds by } \\
\text { sector and by region. }\end{array}$ & $\begin{array}{l}\text { (30. Dec. 2014) } \\
\text { Geographic and sector disparities persist in the } \\
\text { allocation of funds. }\end{array}$ & \\
\hline \multirow{3}{*}{9} & \multirow{3}{*}{$\begin{array}{l}\text { Aid programs are effectively monitored } \\
\text { by donors and by the Afghan } \\
\text { government. }\end{array}$} & 9.1 & $\begin{array}{l}\text { A nationwide independent commission for aid } \\
\text { effectiveness is established by MoF with the } \\
\text { support of donor community }\end{array}$ & $\begin{array}{l}\text { (30. Dec. 2014) } \\
\text { No independent, Afghan-led body exists to } \\
\text { monitor aid programs. }\end{array}$ & \\
\hline & & 9.2 & $\begin{array}{l}\text { The MoF in consultation with donor } \\
\text { representatives, develops a plan for such a } \\
\text { commission that would issue annual reports } \\
\text { assessing the effectiveness of all foreign- } \\
\text { assistance delivered to Afghanistan. }\end{array}$ & $\begin{array}{l}\text { (30. Dec. 2014) } \\
\text { No such plan has been drafted. }\end{array}$ & \\
\hline & & 9.3 & $\begin{array}{l}\text { Agreement is reached between the Afghan } \\
\text { government( MoF \& MoEC) and major } \\
\text { international stakeholders to draw up a } \\
\text { comprehensive set of aid effectiveness } \\
\text { indicators. }\end{array}$ & $\begin{array}{l}\text { (30. Dec. 2014) } \\
\text { No agreed-upon set of aid-effectiveness } \\
\text { indicators exists that can be used both by the } \\
\text { government and by the donor community. }\end{array}$ & \\
\hline 10 & \begin{tabular}{|l|} 
Increased amount of donor assistance \\
channeled through national budget, if the \\
Afghan government meets defined \\
commitments to reduce corruption and \\
increase financial transparency.
\end{tabular} & 10.1 & $\begin{array}{l}\text { Key donors and GIRoA (MoF) adhere to the } \\
\text { benchmarks set forth in the TMAF. }\end{array}$ & $\begin{array}{l}\text { (30. Dec. 2014) } \\
\text { While some donors are already in compliance, } \\
\text { insufficient information exists to render a } \\
\text { judgment on every donor. }\end{array}$ & \\
\hline
\end{tabular}

